\title{
THE ROLE OF FEMALE INDUSTRIAL LABOR IN THE LATE COLONIAL NETHERLANDS INDIES'
}

\section{Siddharth Chandra}

\section{Introduction}

One of the least studied aspects of colonial economic history is the role of women in the economy. The focus of the occasional study of this role has been the work of women in agriculture or as household producers. The position of women in a number of Asian former colonies has likely changed substantially since the turn of the last century. The directions of these developments are often specific in nature, and are well understood only in the context of their initial conditions. ${ }^{2}$

In the case of Indonesia, women are gaining access in increasing numbers to educational and economic opportunities that were unavailable to them during the colonial era. The active involvement of women in the labor-intensive garment and footwear factories established during the investment boom of the 1980 s and early

\footnotetext{
1 This paper was presented at the Annual Meeting of the Association for Asian Studies in San Diego in March 2000 and at the Annual Meeting of the Eastern Economic Association in New York in February 2001.

2 In the case of the United States, for example, Claudia Goldin emphasizes the importance of historical benchmarks in analyzing the progress of female labor. To do so, she reviews the considerable literature on this subject. See Claudia Goldin, Understanding the Gender Gap: An Economic History of American Women (New York: Oxford University Press, 1990). Rigorous quantitative research on the historic economic role of women in the colonial economies of Asia and Africa, on the other hand, is very scarce. See Christine Dobbin, "The Search for Women in Indonesian History," in Kartini Centenary: Indonesian Women Then and Now, ed. Ailsa G. T. Zainuddin (Clayton, Victoria: Monash University Press, 1980) on the related absence of women in scholarship on the history of Indonesia.
} 
1990 s has become emblematic of this change. ${ }^{3}$ As is evident from a recent detailed survey of the state of research on the economic history of the region, however, no quantitative research has been done on female labor in industry in Southeast Asia in the early twentieth century. ${ }^{4}$ We would be unable to assess and understand the magnitude of these more recent changes, both in extent and in intensity, without characterizing some set of historical benchmarks.

The first objective of this study is to characterize these initial conditions for Indonesia. These conditions are "initial" in the sense that the data used in the subsequent analysis predate by four years the first Indonesian Women's Congress, held on December 22-26, 1928, and by one year a key piece of legislation affecting women's economic rights, namely the bill, aimed at limiting female night labor, discussed in the Volksraad in $1925 .^{5}$ The defining characteristics of female industrial labor just after World War I are examined with a view to providing a comprehensive characterization of female industrial labor in the late colonial Netherlands Indies. An unusual aspect of this study is the combination of its colony-wide scope, its historical context, and the quantitative methodology used to summarize and analyze the data. Because of the richness of the data, a number of inter-regional and inter-sectoral comparisons can be made. It is hoped that these will serve as a benchmark for similar studies using more recent and equally, if not more, detailed data.

While the role of female industrial labor in colonial Indonesia is an under-explored subject, a preliminary agenda for such research has already been set by the work of Elsbeth Locher-Scholten, whose research focuses on female labor in agriculture. ${ }^{6}$ In that study, the author uses data for female agricultural labor to demonstrate that Indonesian women worked more for reasons of economic necessity than they did for traditional (adat) reasons. In particular, along the lines of the now dominant tradition ${ }^{7}$ of new institutional economic history, the author finds that economic necessity led to a

3 For a discussion of this boom, see Mari Pangestu and Manggi Habir, "Survey of Recent Developments," Bulletin of Indonesian Economic Studies 26 (1990): 3-40, for example. For the effects of this boom on the industrial labor market, see Gavin Jones, "Labour Force and Labour Utilization," in The Demographic Dimension in Indonesia's Development, ed. Graeme J. Hugo, Terence H. Hull, Valerie J. Hull, and Gavin Jones (Kuala Lumpur: Oxford University Press, 1987).

${ }^{4}$ See Ian Brown, Economic Change in South-East Asia (Kuala Lumpur: Oxford University Press, 1997). The survey is as valuable for its coverage of research on the region as it is for indications of gaps in the research.

${ }^{5}$ For the former, see Department of Information, Republic of Indonesia, The Indonesian Women's Movement: A Chronological Survey of the Women's Movement in Indonesia (Jakarta: Department of Information, Republic of Indonesia, 1968), pp. 11-12. For the latter, see Elsbeth Locher-Scholten, Women and the Colonial State: Essays on Gender and Modernity in the Netherlands Indies 1900-1942 (Amsterdam: Amsterdam University Press, 2000), pp. 52-55. This essay was initially published in 1987. The Volksraad bill was motivated at least in part by notions of the proper role of women in society and by concern for the safety of women workers.

6 Locher-Scholten, Women and the Colonial State.

${ }^{7}$ In this tradition, institutions are modeled using a functional approach-they exist for a purpose, and often an economic one, and their existence or non-existence profoundly shapes outcomes. For influential work on this subject, see Mancur Olson, The Logic of Collective Action: Public Goods and the Theory of Groups (Cambridge: Harvard University Press, 1971) on the development of institutions, and Douglass C. North, Institutions, Institutional Change, and Economic Performance (Cambridge: Cambridge University Press, 1990) on the role of institutions in economic outcomes. 
tradition (or institutions) of female economic participation. The then-popular notion in the West concerning the proper role of the woman as a housebound mother and wife was, therefore, foreign to the average Indonesian. ${ }^{8}$ Limitations of Locher-Scholten's study include its focus on Java and Madura to the exclusion of the Outer Islands, and its focus on the "traditional" agricultural sector at a time when industry in the Netherlands Indies had boomed, creating new markets for labor, both male and female. ${ }^{9}$ This study fills in some of these gaps.

The second objective of this paper is to explore the dynamic and (at the time) relatively young industrial formal ${ }^{10}$ sector for evidence of the role of female labor, both in Java and Madura and in the Outer Islands. If female labor played a role in the more "modern" industrial sector that was as important as its role in the "traditional" agricultural sector, then we have a piece of evidence that potentially confirms the importance of economic factors relative to tradition. In this case, the lengthy process of development of traditions can be inferred to be unimportant relative to the immediate needs of the economy. If, on the other hand, this role was substantially smaller, then one must accord tradition its due place. In the latter scenario, traditional institutions act as the vehicles through which forces of economic necessity are manifested as labor market outcomes. Until these institutions develop, however, markets will not function at their full potential, and economic outcomes will not fully reflect the interplay of economic forces.

This study is organized as follows. First, the related literatures on the historical economic role of women in industry in general and in Indonesia in particular are briefly explored. After discussion of the data, an overview of the role of women in the industrial labor market is presented, with notes on and references to prior work that is related to the findings. Then, the presence of female labor is analyzed along industrial and regional lines, with discussion of the issue of gender-based segregation and specialization. Next, a brief examination of wages is provided, with quantification of such phenomena as the male-female wage gap. Finally, the findings are used to inform the "necessity vs. tradition (adat)" question.

\section{Literature Review}

Because this is the study of a segment of the labor force with special characteristics, it draws on the vast literature on segmentation in labor economics. This literature includes studies of racial and gender wage differentials, and studies of skill premia, or the rate at which people at different levels of the skill hierarchy are

8 Ibid., p. 71.

9 The data used in that study come from a variety of sources, including the 1930 census of the Netherlands Indies. See Volkstelling 1930 (Batavia: Landsdrukkerij, 1934), various volumes. For a related and likewise geographically delimited study that examines female labor in Java at an earlier time, see Peter Boomgaard, "Female Labour and Population Growth in Nineteenth-Century Java," Review of Indonesian and Malaysian Affairs 15,2 (1981): 9-10.

10 "Formal" refers to economic activity that is recorded by the government, usually for the purpose of taxation or statistical analysis. 
106 Siddharth Chandra

rewarded for their labor. ${ }^{11}$ Such studies generally focus on the measurement of wage differentials, the causes of these differentials, and changes over time in these differences. A second theme in this literature relates to segregation and skill-bias, or the extent to which a particular segment of the labor force (based on a defining characteristic such as gender or race) is represented disproportionately in particular sectors or levels of the skill hierarchy. ${ }^{12}$ In this study, some attention will be paid to gender-based occupational segregation and skill-bias, and to gender-specific wage differentials. A second and closely related strand of research on which this study draws is the literature on the historical economic role of women. While the body of research in this area is growing, scant attention has been paid to the quantitative analysis of the economic role of women in colonial economies, and especially in industry. The literature in economic history which focuses on women deals mostly with the United States and a few western European economies. ${ }^{13}$

This analysis is also related to the work on female industrial labor in Java. ${ }^{14}$ At present, this literature is rather thin and consists mainly of studies with limited geographic and sectoral scope. The work of Locher-Scholten, which makes passing reference to industrial labor, has already been discussed above. ${ }^{15}$ A study close in approach to this one is Diane Lauren Wolf's socioeconomic analysis of female industrial labor in a small kecamatan south of Semarang, in north-central Java in the 1980 s. ${ }^{16}$ An equally important but again somewhat thin body of literature comprises the work on the feminist movement in the Netherlands Indies, which originated in Java in the early part of the past century. The collection of Kartini's letters figures as the classic text in this body of work, expressing the views of a female educated member of the Javanese aristocracy in correspondence with her Dutch friends. ${ }^{17}$ Interestingly, but not surprisingly, the letters pay little attention to the role and condition of female industrial labor in the Netherlands Indies. Because the women's movement in Indonesia

11 For a study of skill premia, see Chinhui Juhn, Kevin M. Murphy, and Brooks Pierce, "Wage Inequality and the Rise in Returns to Skill," Journal of Political Economy 101 (1993): 410-442. For a study of gender differentials, see Claudia Goldin and Solomon Polachek, "Residual Differences by Sex: Perspectives on the Gender Gap in Earnings," American Economic Review 77 (1987): 143-51. For a broader analysis of wage differentials, see Francine D. Blau and Lawrence M. Kahn, "International Differences in Male Wage Inequality: Institutions versus Market Forces," Journal of Political Economy 104 (1996): 791-837.

12 A study that emphasizes these phenomena is Solomon Polachek, "Occupational Segregation and the Gender Wage Gap," Population Research and Policy Review 6 (1987): 47-67.

13 Perhaps the most comprehensive modern summary of such work is Goldin's Understanding the Gender Gap.

14 Female industrial labor in the Outer Islands, by contrast, has received little or no attention from social scientists.

15 Locher-Scholten, Women and the Colonial State.

16 See Diane Lauren Wolf, Factory Daughters: Gender, Household Dynamics, and Rural Industrialization in Java (Berkeley: University of California Press, 1992).

17 A collection of Kartini's letters in translation was published as Joost Coté, Letters from Kartini: An Indonesian Feminist, 1900-1904 (Clayton, Victoria: Monash Asia Institute, Monash University, 1992. Translation). See also Joost Coté, On Feminism and Nationalism: Kartini's Letters to Stella Zeehandelaar, 1899-1903 (Clayton: Monash University, 1995). 
is formally said to have started in 1928,18 the study of the economic position of women in industry in the early 1920 s assumes greater significance in that it makes for a chronologically appropriate benchmark against which to evaluate changes in the status of female industrial labor in Indonesia since the founding of the movement. ${ }^{19}$

\section{Data}

The Netherlands Indies provide fertile ground for quantitative research on the economic position of women in the colonial setting because of the quality and quantity of data available on the subject. The data used in this paper are derived from the annual Koloniale Verslagen (Colonial Reports) from 1918 to 1924, and specifically, the tables which provide a breakdown of wages by region, skill level, race, industry, and gender. ${ }^{20}$ While the data on wages are themselves reliable, and the samples are large in terms of the number of women covered and broad in terms of sectoral and geographic scope, they should not be considered exhaustive. There is reason to believe that part of the overall increasing trend in the number of women covered by the data (see Figure 1a, below) and the number of industry-region pairs (see Figure 1b, below) is the result of the increasing penetration of the Netherlands Indies data gathering machine into preexisting regions and/or sectors. ${ }^{21}$

According to the tables, the data cover industrieele inrichtingen, or industrial establishments. ${ }^{22}$ Activities that were classified as "industrial" at the time included repairing automobiles and bicycles, in addition to activities which are more commonly

\footnotetext{
${ }^{18}$ See, for example, Kesatuan Pergerakan Wanita Indonesia, Peringatan 30 Tahun Kesatuan Pergerakan Wanita Indonesia (Djakarta: Pertjetakan Negara, 1958), commemorating the thirtieth anniversary of the Kesatuan Pergerakan Wanita Indonesia, or the United Indonesian Women's Movement.

${ }^{19}$ While there is a large literature on feminism in Indonesia by modern scholars, it has, by and large, skirted systematic treatment of economic issues. See, for example, Rita Smith Kipp, "Emancipating Each Other: Dutch Colonial Missionaries' Encounters with Karo Women in Sumatra, 1900-1942," in Domesticating the Empire: Race, Gender, and Family Life in French and Dutch Colonialism, ed. Julia Clancy-Smith and Frances Gouda (Charlottesville and London: University Press of Virginia, 1998), pp. 211-35; Jean Gelman Taylor, ed., Women Creating Indonesia: The First Fifty Years (Clayton: Monash Institute, 1997); Frances Gouda, "The Gendered Rhetoric of Colonialism and Anti-Colonialism in Twentieth-Century Indonesia," Indonesia 55 (1993): 1-22; and Susan Blackburn and Sharon Bessell, "Marriageable Age: Political Debates on Early Marriage in Twentieth-Century Indonesia," Indonesia 63 (1997): 107-41.

20 See Department van Koloniën, Koloniaal Verslag ( 's-Gravenhage, 1918-1925), henceforth referred to as the Colonial Reports. These tables are in the Bijlagen or Appendices which form the "Statistical Overview," the second part of the Colonial Reports for this time period. Specifically, these are, for 1918, 1920, 1921, and 1922 , Bijlage GG, for 1919 and 1923, Bijlage FF, and for 1924, Bijlage BB. The choice of years was based on their location in time (see above) and availability of data-the Colonial Reports prior to 1918 do not contain a breakdown of wages by gender. This series ends in 1924 .

${ }^{21}$ An industry-region pair is an observation for one industry in a region in any year. For example, the statistics for the lime kiln industry in Banyumas counts as one industry-region pair so long as it appears in at least one edition of the Colonial Reports between 1918 and 1924. The clearest evidence of the trend in data collection is seen in similar improvements in depth and scope of reporting over the period 1908-1917. This trend, paralleling the "bureaucratic efflorescence" of the time, continued through the period under consideration here and is clearly evident from the increasing size and scope of successive editions of the Colonial Reports.

22 Industries were defined as closed work spaces. See Locher-Scholten, Women and the Colonial State, p. 53.
} 
108 Siddharth Chandra

Figure 1a: Number of Women in Sample (1918-1924)

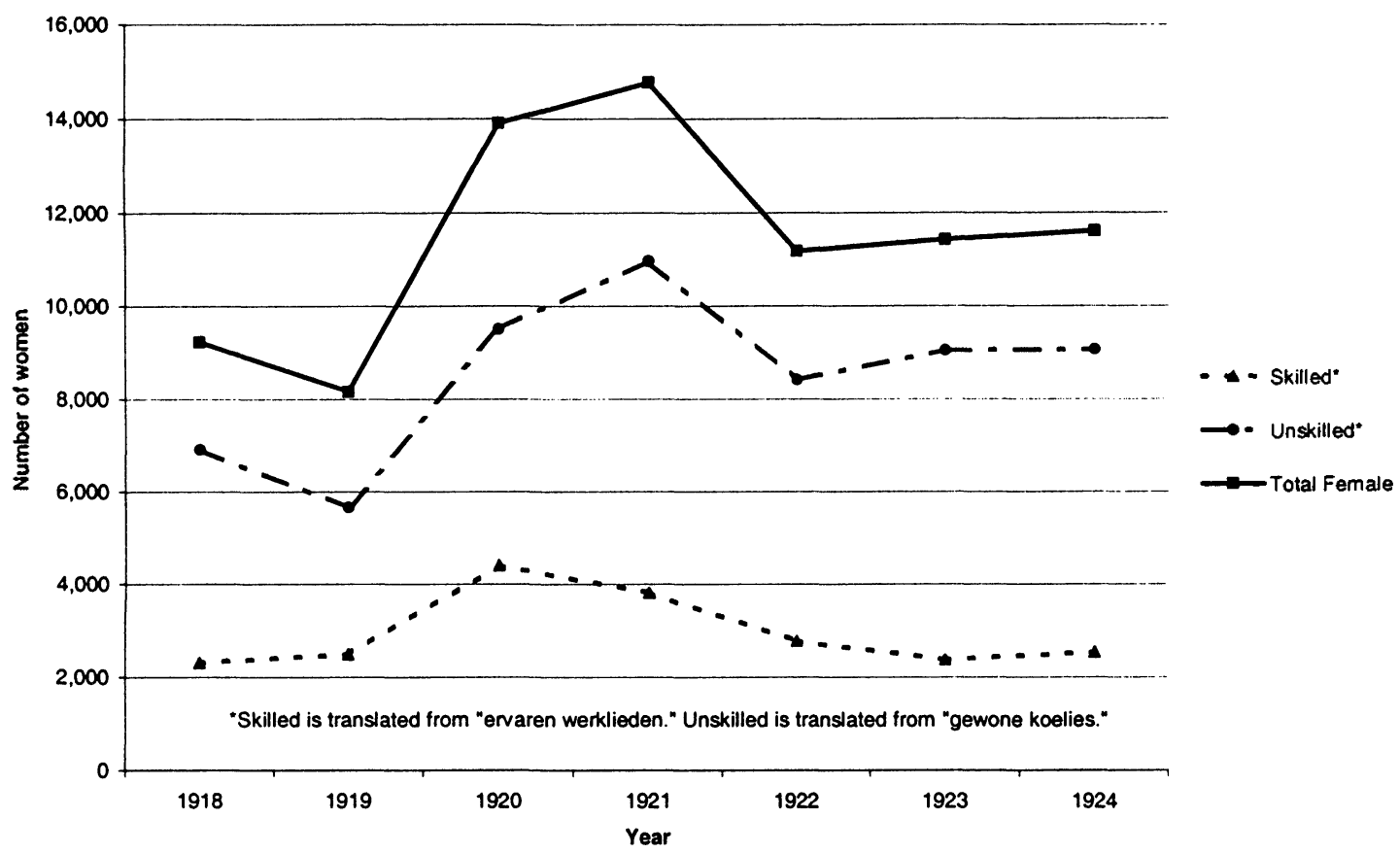

Figure 1b: Industry-Region Pairs with Women Employees in Sample (1918-1924)

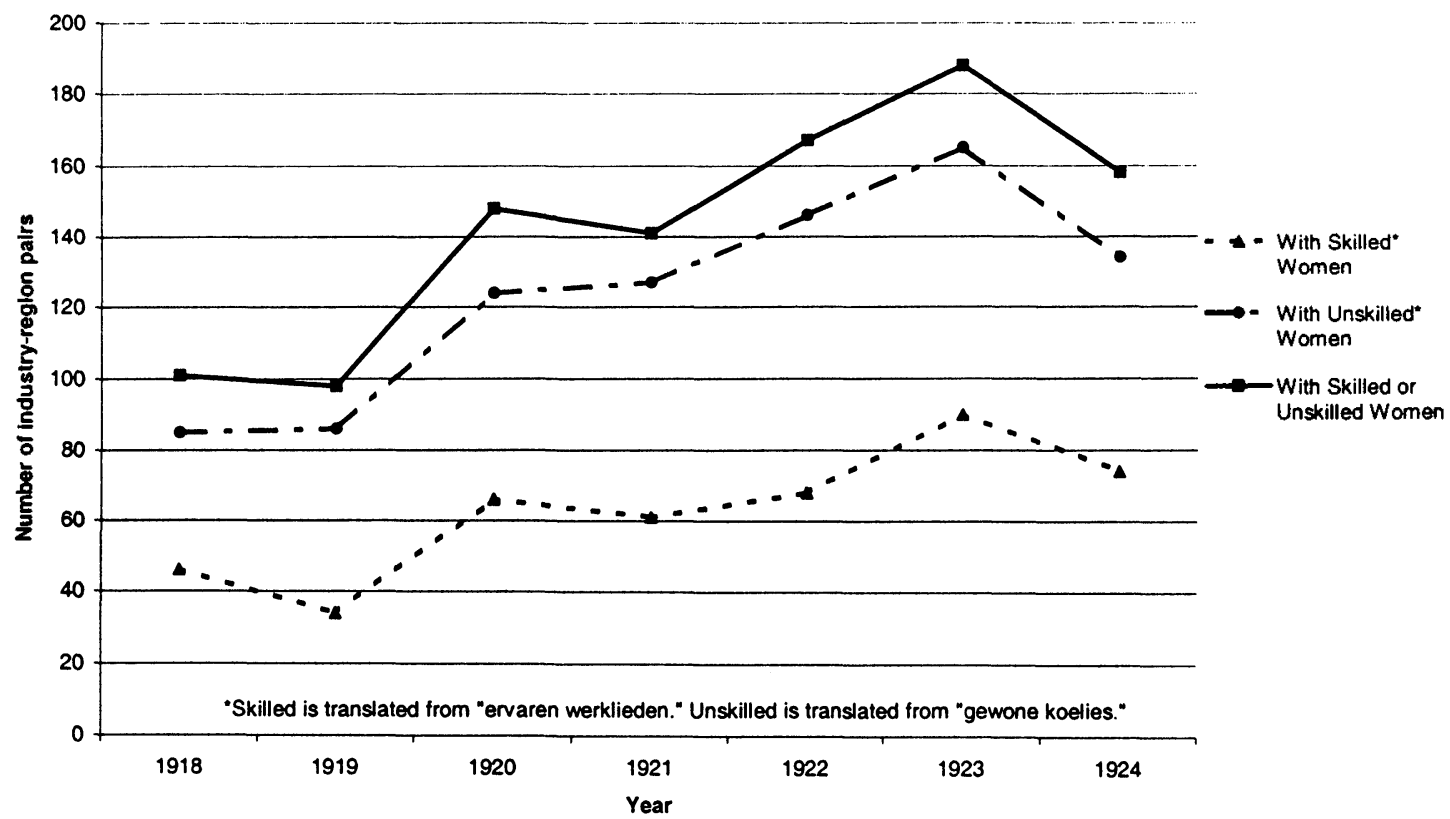


understood as industrial today, such as leather tanning, the manufacture of textiles, and making tahu and baking, which would likely be characterized as belonging to the food or food-processing sectors today. ${ }^{23}$ Figures $2 \mathrm{a}$ and $2 \mathrm{~b}$ (below) show, respectively, the total number of different industries for which data are available by region in at least one year, and the total number of different regions for which data are available by industry in at least one year. ${ }^{24}$ The residencies of Java, and especially those in the more industrialized north, show the greatest diversity of industrial activity. Residencies with traditional urban centers in particular, including Jakarta, Priangan (Bandung), Surabaya, and Semarang, are the most industrially diverse. ${ }^{25}$ Given the time and locations for which the data were collected, the geographic and sectoral breadth and the temporal depth of the data are quite remarkable, if not unique.

Table 1 (see below) is a sample of the original data used in the analysis. ${ }^{26}$ Over the period in question, wages for indigenous women are available alongside those for men. ${ }^{27}$ These wages are only given for the skilled artisan (ervaren werklieden) and unskilled "coolie" (gewone koelies) labor categories. Apparently women did not reach the foreman (mandoer) level in the industrial labor market in numbers significant enough to warrant entering mandoer wages for women as a separate category. ${ }^{28}$

As with most historical microeconomic data, the wage data in the Colonial Reports have a number of drawbacks. These include, first, their presentation at the

${ }^{23}$ For a brief but informative account of manufacturing in the Netherlands Indies from 1890 to 1942 and the activities this entailed, see W. A. I. M. Segers, Changing Economy in Indonesia: Manufacturing Industry 1870-1942, in Changing Economy in Indonesia series, vol. 8 (Amsterdam: Royal Tropical Institute, 1987), pp. 16-40. Modern usage of the label "industrial" refers specifically to the system of Standard Industrial Classification (SIC) codes, the widely accepted standard in quantitative economic research.

${ }^{24}$ This does not mean that the panel used here is balanced (i.e., that data available for each industry-region pair were available for each of the seven years under consideration).

25 Indonesianized names are used in place of the original colonial names. In some cases, the administrative regions for which data were collected do not have exact modern-day equivalents. These colonial regions with Indonesianized names should not be confused with the modern-day administrative regions called by the same names.

${ }^{26}$ For a discussion of wage data for the Netherlands Indies, general trends in wages, and related issues including labor legislation, see Nico Dros, Changing Economy in Indonesia: Wages 1820-1940, in Changing Economy in Indonesia series, vol. 13 (Amsterdam: Royal Tropical Institute, 1992), pp.11-32. For a discussion of wage data from the Colonial Reports, see Siddharth Chandra, "Race, Inequality, and Anti-Chinese Violence in the Netherlands Indies," Explorations in Economic History 39 (2002): 88-112.

27 There is no information about women from other racial categories. In terms of racial classification, the subject population of the Netherlands Indies was divided into two groups, the Inlanders, or indigenous people, and the Vreemde Oosterlingen, or Foreign Orientals (Asiatics), a category dominated by people of Chinese ethnicity. For a discussion of these legal categories, see Cornelis Fasseur, "Cornerstone and Stumbling Block; Racial Classification and the Late Colonial State in Indonesia," in The Late Colonial State in Indonesia: Political and Economic Foundations of the Netherlands Indies 1880-1942, ed. Robert Cribb (Leiden: KITLV Press, 1994), pp. 31-55. A later version of this paper was published as "Hoeksteen en Struikelblok. Rassenonderscheid en overheidsbeleid in Nederlands-Indie," in Cornelis Fasseur, De Weg naar het Paradijs en andere Indische Geschiedenissen (Amsterdam: Bert Bakker, 1995), pp. 139-71.

28 This is an example of "statistical discrimination" as defined in Goldin, Understanding the Gender Gap, pp. 88-89. 
Figure 2a: Total Number of Different Industries for which Data are available by Region

(1918-1924)

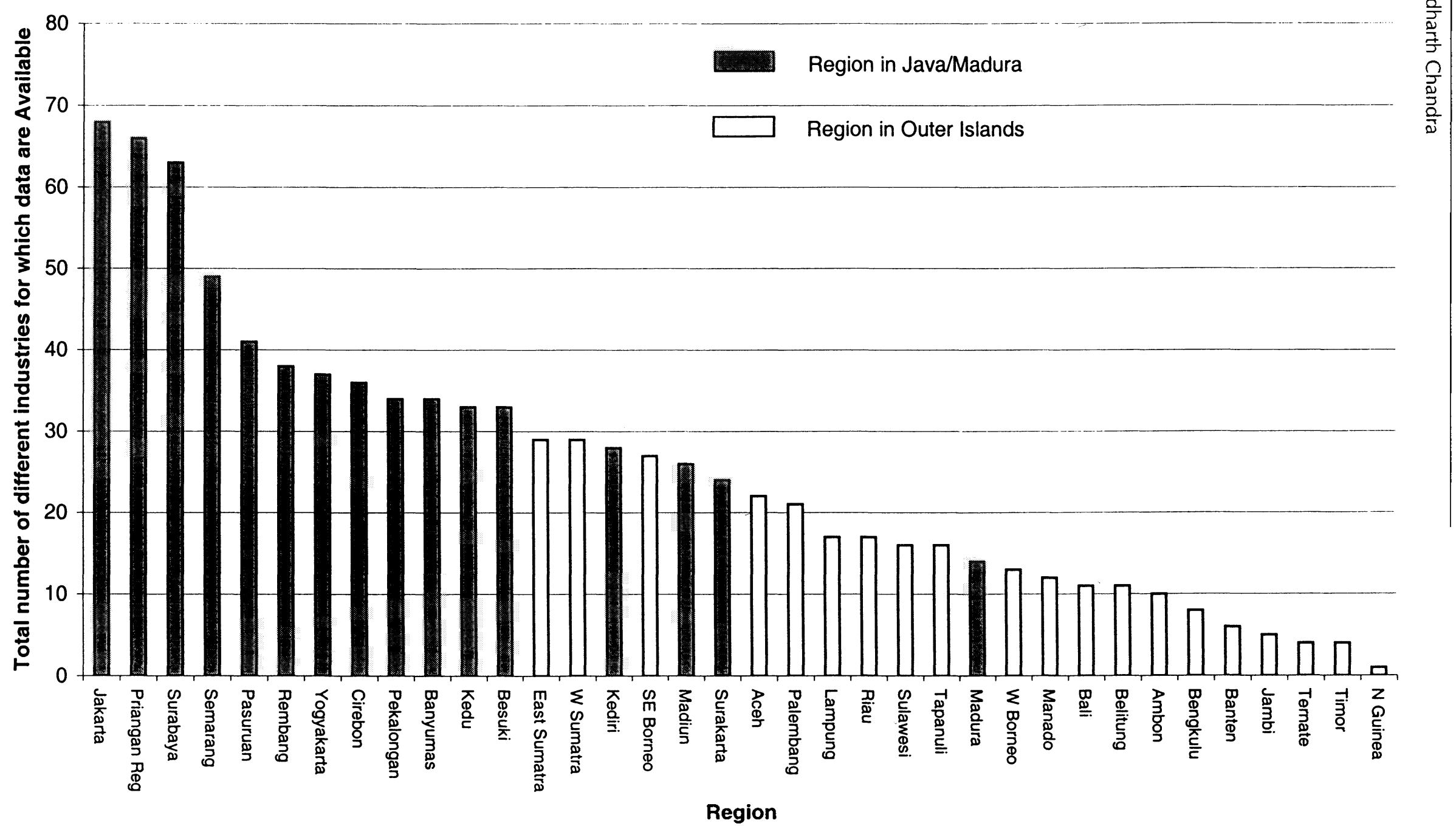


Figure 2b: Total Number of Different Regions for which Data are available by Industry*

(1918-1924)

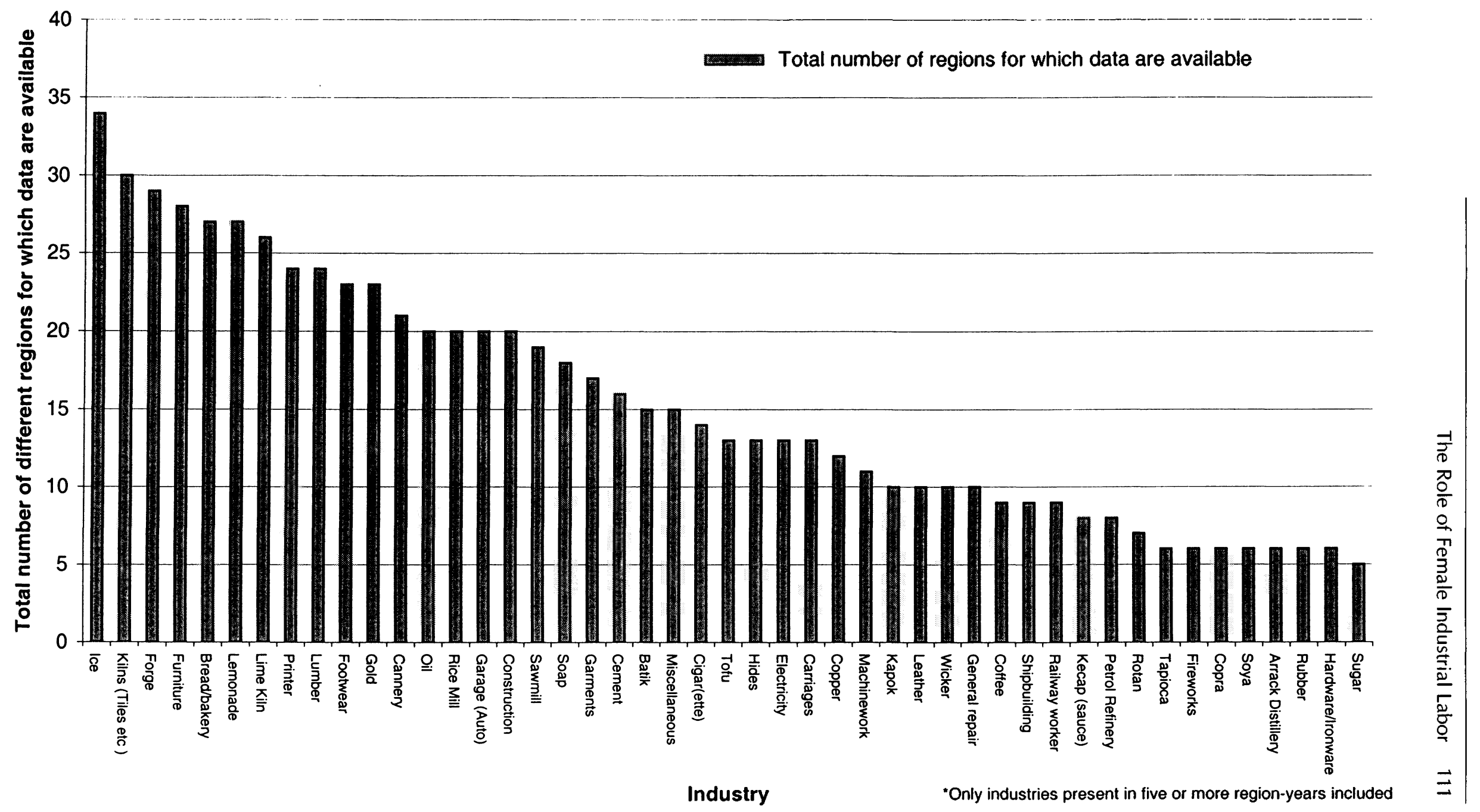


112 Siddharth Chandra

Table 1: A Comparison of Wages for Selected Professions for Indonesians and Foreign Asiatics (Mostly Chinese) in Banyumas, 1920

\begin{tabular}{|c|c|c|c|c|c|c|c|c|c|c|}
\hline & & & \multicolumn{8}{|c|}{ Total Labor } \\
\hline & & & \multicolumn{2}{|c|}{ Foremen } & \multicolumn{3}{|c|}{ Skilled artisans } & \multicolumn{3}{|c|}{ Unskilled "coolies" } \\
\hline \multirow[t]{2}{*}{ Place/Sector } & \multirow{2}{*}{$\begin{array}{c}\text { Total } \\
\text { Estabs }\end{array}$} & \multirow{2}{*}{$\begin{array}{l}\text { Power } \\
\text { Source }\end{array}$} & \multirow[t]{2}{*}{ Chinese } & \multirow[t]{2}{*}{ Indonesian } & \multirow[t]{2}{*}{ Chinese } & \multicolumn{2}{|c|}{ Indonesian } & \multirow[t]{2}{*}{ Chinese } & \multicolumn{2}{|c|}{ Indonesian } \\
\hline & & & & & & Male & Female & & Male & Female \\
\hline \multicolumn{11}{|l|}{ Banyumas } \\
\hline Lime kiln & 6 & Hand & -- & -- & $\ldots$ & 32 & $\ldots$ & - & $\cdots$ & -- \\
\hline Tile factory & 36 & Hand & --- & $\ldots$ & $\ldots$ & $\ldots$ & $\ldots$ & -- & 53 & -- \\
\hline Oil & 1 & Water & -- & 23 & $\ldots$ & 35 & -- & -- & 60 & 40 \\
\hline
\end{tabular}

\begin{tabular}{|c|c|c|c|c|c|c|c|c|}
\hline & \multicolumn{8}{|c|}{ Daily Wage in Guilders* } \\
\hline & \multicolumn{2}{|c|}{ Foremen } & \multicolumn{3}{|c|}{ Skilled artisans } & \multicolumn{3}{|c|}{ Unskilled "coolies" } \\
\hline & \multirow[t]{2}{*}{ Chinese } & \multirow[t]{2}{*}{ Indonesian } & \multirow[t]{2}{*}{ Chinese } & \multicolumn{2}{|c|}{ Indonesian } & \multirow[t]{2}{*}{ Chinese } & \multicolumn{2}{|c|}{ Indonesian } \\
\hline Place/Sector & & & & Male & Female & & Male & Female \\
\hline \multicolumn{9}{|l|}{ Banyumas } \\
\hline Lime kiln & -- & -- & --- & 0.44 & --- & -- & -- & -- \\
\hline Tile factory & $-\cdots$ & --- & --- & -- & $\ldots$ & $-\cdots$ & 0.26 & $\cdots$ \\
\hline Oil & --- & 0.55 & $-\ldots$ & 0.60 & -- & -- & 0.35 & 0.20 \\
\hline
\end{tabular}

*One Guilder $=100$ cents. After the 1920 edition of the Colonial Report, some of the wage data consist of ranges (a high wage and a low wage) for a given category of labor.

* Unskilled "coolies" is translated from Gewone koelies, Skilled artisans from Ervaren werklieden, and Foremen from Mandoers.

Source: Koloniaal Verslag, 1920, Bijlage GG, p. 2. 
region-industry level, rather than the firm level. ${ }^{29}$ Second, any variations in wages across workers in a specific year/region/industry/skill cell are recorded only for the years 1921 and later. Even in these years, only the extremes (i.e., the lowest and highest wages paid) of the wage distribution are reported. Third, apart from the threeway skill-level characterization described above, no information is provided about the specific tasks undertaken by men and women in the same year/region/industry/skill cell. From descriptions of activity in various industries, it appears that there was substantial specialization in tasks by gender. $^{30}$ Fourth, apart from the foreman/artisan/"coolie" categorization, which is in itself an indicator of skill and likely determined by experience, no data are provided on experience and education, two variables that enter into most standard analyses of wages. ${ }^{31}$

Counterbalancing these drawbacks are some unusual strengths of the data set. First, they cover the entire Netherlands Indies and a broad range of industrial activity, even though they exclude such industrial aspects of agriculture as sugar-milling.32 Second, the data are available in a continuous panel of seven years, an attribute that early twentieth-century data for even the US do not possess. Third, we have information about the power source for each industry, which provides a convenient proxy for technology, a breakdown of information by race, and indicators of the size of each sector in a region by way of the number of establishments and total number of employees engaged in that sector.

\section{An Overview of the Role of Women in Industrial Labor}

Overall, as might be expected, women played a small role relative to men in industry in the Netherlands Indies in the $1920 \mathrm{~s}$. Of a total 80,690 workers covered by the data in 1918, for example, only 9,224, or 11.4 percent of them, are women. Column 2 in Table 2a shows women as a percentage of total industrial labor as recorded in the Colonial Reports. This is significantly lower than the figure for women in agricultural

29 This problem is not specific to data for the Netherlands Indies. The Working Women Report of 1888 for the US also contains data in industry-city cells. See US Commissioner of Labor, Fourth Annual Report of the Commissioner of Labor, 1888: Working Women in Large Cities (Washington, DC: Government Printing Office, 1889).

30 See, for example, the quote in footnote 37 on the manufacture of kapok. For an example in the context of modern Indonesian industry, see the description in Diane Lauren Wolf, Factory Daughters: Gender, Household Dynamics, and Rural Industrialization in Java, pp. 122-123, of "male" and "female" tasks in a bread and a noodle factory in Java. For a discussion of this issue in the context of the US, see Goldin, Understanding the Gender Gap, pp. 74-82.

31 It can, however, be argued that education was uniformly low among industrial laborers in the Netherlands Indies at the time. For a summary of education in the late Netherlands Indies, see Paul W. van der Veur, Education and Social Change in Colonial Indonesia (I), Papers in International Studies Southeast Asia Series No. 12 (Athens: Ohio University Center for International Studies Southeast Asia Program, 1969). For this reason, however, the analysis in this paper de-emphasizes wages and focuses on participation, segregation, and specialization.

32 For the importance of this industry in Java, see Margaret Leidelmeijer, Van Suikermolen tot Grootbedrijf. Technische Vernieuwing in de Java-Suikerindustrie in de Negentiende Eeuw, Series III, no. 25 (Amsterdam: Nederlandsch Economisch-Historisch Archief, 1997). 
114 Siddharth Chandra

Java, which stands at 43.5 percent. ${ }^{33}$ Column 2 also shows that the position of women changed little over the seven years for which the data were published.

Column 3 in Table $2 a$ (below) shows the total wage bill paid to women, and Column 4 shows this wage bill as a percentage of the total wage bill for labor reported in the Colonial Reports. The percentages in Column 4 are less than half the percentages in Column 2. There are two reasons for this. First, as mentioned above, a form of "statistical discrimination" was at work-women did not have access to certain highskill and high-wage jobs. As a result, the fraction of total wages earned by men is larger than the fraction of men in the labor force. Second, even in jobs to which they had access, women were, on average, earning lower wages than their male counterparts. This will be demonstrated below. Parallel statistics for Java and Madura (Table 2b) and the Outer Islands (Table 2c) show an interesting difference between the two regions. Women were a substantially more important part of the industrial labor force in Java and Madura, although they still were a small minority, than they were in the Outer Islands.

In terms of geographic and sectoral scope of involvement, we see that this was somewhat higher for female labor than the proportion of women in labor or female wages in the total wage bill. Of a total of thirty-six regions, twenty-nine had industries in which women were employed (see Figure 3, below), and of the forty-seven sectors for which there are at least five region-year observations, forty-two had at least one establishment in which women were employed (see Figure 4, below). Table 3a shows the penetration of female labor by region, industry, and industry-region over time. Penetration here is defined as the presence of at least one female worker in a region (across all industries), industry (across all regions), or industry-region. In general, the regional and sectoral scope of female labor, described in Table $3 a$, is higher in percentage terms than the depth of penetration, described in Table 2 . In over half of the regions of the Netherlands Indies, in roughly half of the sectors of industry, and in about a third of the region-sectors, women were represented in the labor pool. The comparison of Java and Madura and the Outer Islands (Tables $3 b$ and 3c), however, reveals that this representation was by no means uniform across the Netherlands Indies. In particular, women worked in industry in almost all the regions of Java and Madura, while less than half of the regions of the Outer Islands had female labor in industry. Over half of the sectors in Java and Madura had female labor, while the corresponding figure for the Outer Islands is less than one fifth. Roughly one third of the region-sectors in Java and Madura had female labor, while the corresponding figure for the Outer Islands is less than one tenth.

Combining the information in Tables $2 \mathrm{a}-\mathrm{c}$ and $3 \mathrm{a}-\mathrm{c}$ reveals that the position of women in industry in Java and Madura was substantially better in terms of geographic and sectoral representation than it was in the Outer Islands. And, while the overall picture of women in industrial labor is one of a broad but generally superficial presence, it will be shown in the following section that there were, in fact, a few

${ }^{33}$ Locher-Scholten, Women and the Colonial State, p. 60. 
Table 2a: Overall Importance of Female Industrial Labor, Netherlands Indies

\begin{tabular}{|c|c|c|c|c|}
\hline Year & $\begin{array}{c}\text { No. of Women } \\
\text { in Data }\end{array}$ & $\begin{array}{c}\text { As \% of } \\
\text { Total Labor }\end{array}$ & $\begin{array}{c}\text { Wage Bill for } \\
\text { Female Labor* }\end{array}$ & $\begin{array}{c}\text { As \% of Total } \\
\text { Wage Bill }\end{array}$ \\
\hline 1918 & 9,224 & $11.40 \%$ & 2,332 & $4.50 \%$ \\
\hline 1919 & 8,152 & $10.10 \%$ & 1,952 & $3.40 \%$ \\
\hline 1920 & 13,906 & $15.20 \%$ & 3,629 & $6.20 \%$ \\
\hline 1921 & 14,759 & $18.70 \%$ & $3,530(\mathrm{~L})-5,896(\mathrm{H})$ & $7.5 \%(\mathrm{~L})--7.4 \%(\mathrm{H})$ \\
\hline 1922 & 11,172 & $12.90 \%$ & $4,306(\mathrm{~L})-5,454(\mathrm{H})$ & $6.5 \%(\mathrm{~L})--4.8 \%(\mathrm{H})$ \\
\hline 1923 & 11,421 & $12.10 \%$ & $2,945(\mathrm{~L})-4,320(\mathrm{H})$ & $3.8 \%(\mathrm{~L})--3.5 \%(\mathrm{H})$ \\
\hline 1924 & 11,598 & $15.60 \%$ & $2,788(\mathrm{~L})-3,760(\mathrm{H})$ & $5.6 \%(\mathrm{~L})--5.1 \%(\mathrm{H})$ \\
\hline
\end{tabular}

Table 2b: Overall Importance of Female Industrial Labor, Java and Madura

\begin{tabular}{|c|c|c|c|c|}
\hline Year & $\begin{array}{c}\text { No. of Women } \\
\text { in Data }\end{array}$ & $\begin{array}{c}\text { As \% of } \\
\text { Total Labor }\end{array}$ & $\begin{array}{c}\text { Wage Bill for } \\
\text { Female Labor* }\end{array}$ & $\begin{array}{c}\text { As \% of Total } \\
\text { Wage Bill }\end{array}$ \\
\hline 1918 & 8,968 & $13.59 \%$ & 2,246 & $5.71 \%$ \\
\hline 1919 & 7,965 & $12.85 \%$ & 1,890 & $5.04 \%$ \\
\hline 1920 & 13,636 & $17.90 \%$ & 3,518 & $7.50 \%$ \\
\hline 1921 & 13,992 & $22.36 \%$ & $3,138(\mathrm{~L})-5,456(\mathrm{H})$ & $9.42 \%(\mathrm{~L})--8.76 \%(\mathrm{H})$ \\
\hline 1922 & 10,935 & $14.92 \%$ & $3,175(\mathrm{~L})-4,175(\mathrm{H})$ & $5.64 \%(\mathrm{~L})--4.43 \%(\mathrm{H})$ \\
\hline 1923 & 11,012 & $14.33 \%$ & $2,767(\mathrm{~L})-4,137(\mathrm{H})$ & $4.43 \%(\mathrm{~L})--4.02 \%(\mathrm{H})$ \\
\hline 1924 & 11,317 & $18.99 \%$ & $2,693(\mathrm{~L})-3,646(\mathrm{H})$ & $7.45 \%(\mathrm{~L})--6.38 \%(\mathrm{H})$ \\
\hline
\end{tabular}

Table 2c: Overall Importance of Female Industrial Labor, Outer Islands

\begin{tabular}{|c|c|c|c|c|}
\hline Year & $\begin{array}{c}\text { No. of Women } \\
\text { in Data }\end{array}$ & $\begin{array}{c}\text { As \% of } \\
\text { Total Labor }\end{array}$ & $\begin{array}{c}\text { Wage Bill for } \\
\text { Female Labor* }\end{array}$ & $\begin{array}{c}\text { As \% of Total } \\
\text { Wage Bill }\end{array}$ \\
\hline 1918 & 256 & $1.53 \%$ & 86 & $0.69 \%$ \\
\hline 1919 & 187 & $0.98 \%$ & 62 & $0.32 \%$ \\
\hline 1920 & 270 & $1.77 \%$ & 111 & $0.94 \%$ \\
\hline 1921 & 767 & $4.73 \%$ & $392(\mathrm{~L})-440(\mathrm{H})$ & $2.87 \%(\mathrm{~L})--2.56 \%(\mathrm{H})$ \\
\hline 1922 & 237 & $1.75 \%$ & $135(\mathrm{~L})-144(\mathrm{H})$ & $0.97 \%(\mathrm{~L})--0.82 \%(\mathrm{H})$ \\
\hline 1923 & 409 & $2.37 \%$ & $178(\mathrm{~L})-182(\mathrm{H})$ & $1.17 \%(\mathrm{~L})--0.92 \%(\mathrm{H})$ \\
\hline 1924 & 281 & $1.90 \%$ & $94(\mathrm{~L})-115(\mathrm{H})$ & $0.67 \%(\mathrm{~L})--0.67 \%(\mathrm{H})$ \\
\hline
\end{tabular}

*In Guilders, daily wage.

(L): Assuming the low wage. (H) Assuming the high wage. 
116 Siddharth Chandra

Table 3a: Geographic and Sectoral Scope of Female Industrial Labor, Netherlands Indies

\begin{tabular}{|c|c|c|c|c|c|c|}
\hline Year & $\begin{array}{c}\text { Regions with } \\
\text { Female Labor }\end{array}$ & $\begin{array}{c}\text { As \% of } \\
\text { Total } \\
\text { Regions }\end{array}$ & $\begin{array}{c}\text { Sectors with } \\
\text { Female } \\
\text { Labor }\end{array}$ & $\begin{array}{c}\text { As \% of } \\
\text { Total } \\
\text { Sectors }\end{array}$ & $\begin{array}{c}\text { Region-sectors } \\
\text { with Female Labor }\end{array}$ & $\begin{array}{c}\text { As \% of Total } \\
\text { Region-sectors }\end{array}$ \\
\hline 1918 & 21 & $58 \%$ & 27 & $44 \%$ & 98 & $20 \%$ \\
\hline 1919 & 19 & $56 \%$ & 35 & $49 \%$ & 95 & $20 \%$ \\
\hline 1920 & 20 & $65 \%$ & 54 & $57 \%$ & 147 & $31 \%$ \\
\hline 1921 & 22 & $76 \%$ & 51 & $53 \%$ & 136 & $28 \%$ \\
\hline 1922 & 21 & $62 \%$ & 59 & $54 \%$ & 160 & $28 \%$ \\
\hline 1923 & 24 & $69 \%$ & 61 & $55 \%$ & 181 & $32 \%$ \\
\hline 1924 & 22 & $71 \%$ & 53 & $50 \%$ & 150 & $28 \%$ \\
\hline
\end{tabular}

Table 3b: Geographic and Sectoral Scope of Female Industrial Labor, Java and Madura

\begin{tabular}{|c|c|c|c|c|c|c|}
\hline Year & $\begin{array}{c}\text { Regions with } \\
\text { Female Labor }\end{array}$ & $\begin{array}{c}\text { As \% of } \\
\text { Total } \\
\text { Regions }\end{array}$ & $\begin{array}{c}\text { Sectors with } \\
\text { Female } \\
\text { Labor }\end{array}$ & $\begin{array}{c}\text { As \% of } \\
\text { Total } \\
\text { Sectors }\end{array}$ & $\begin{array}{c}\text { Region-sectors } \\
\text { with Female Labor }\end{array}$ & $\begin{array}{c}\text { As \% of Total } \\
\text { Region-sectors }\end{array}$ \\
\hline 1918 & 15 & $88 \%$ & 27 & $47 \%$ & 91 & $27 \%$ \\
\hline 1919 & 16 & $94 \%$ & 32 & $52 \%$ & 90 & $28 \%$ \\
\hline 1920 & 15 & $100 \%$ & 50 & $60 \%$ & 139 & $41 \%$ \\
\hline 1921 & 16 & $100 \%$ & 46 & $54 \%$ & 127 & $34 \%$ \\
\hline 1922 & 15 & $94 \%$ & 56 & $57 \%$ & 153 & $35 \%$ \\
\hline 1923 & 16 & $100 \%$ & 58 & $60 \%$ & 171 & $42 \%$ \\
\hline 1924 & 16 & $100 \%$ & 52 & $56 \%$ & 143 & $34 \%$ \\
\hline
\end{tabular}

Table 3c: Geographic and Sectoral Scope of Female Industrial Labor, Outer Islands

\begin{tabular}{|c|c|c|c|c|c|c|}
\hline Year & $\begin{array}{c}\text { Regions with } \\
\text { Female Labor }\end{array}$ & $\begin{array}{c}\text { As \% of } \\
\text { Total } \\
\text { Regions }\end{array}$ & $\begin{array}{c}\text { Sectors with } \\
\text { Female } \\
\text { Labor }\end{array}$ & $\begin{array}{c}\text { As \% of } \\
\text { Total } \\
\text { Sectors }\end{array}$ & $\begin{array}{c}\text { Region-sectors } \\
\text { with Female Labor }\end{array}$ & $\begin{array}{c}\text { As \% of Total } \\
\text { Region-sectors }\end{array}$ \\
\hline 1918 & 6 & $32 \%$ & 4 & $13 \%$ & 7 & $5 \%$ \\
\hline 1919 & 3 & $18 \%$ & 5 & $15 \%$ & 5 & $3 \%$ \\
\hline 1920 & 5 & $31 \%$ & 7 & $16 \%$ & 8 & $6 \%$ \\
\hline 1921 & 6 & $46 \%$ & 8 & $17 \%$ & 9 & $8 \%$ \\
\hline 1922 & 6 & $33 \%$ & 7 & $16 \%$ & 7 & $5 \%$ \\
\hline 1923 & 8 & $42 \%$ & 8 & $15 \%$ & 10 & $6 \%$ \\
\hline 1924 & 6 & $40 \%$ & 7 & $16 \%$ & 7 & $6 \%$ \\
\hline
\end{tabular}


Figure 3: Scope of Participation of Indigenous Women in Industrial Labor by Region

(1918-1924)

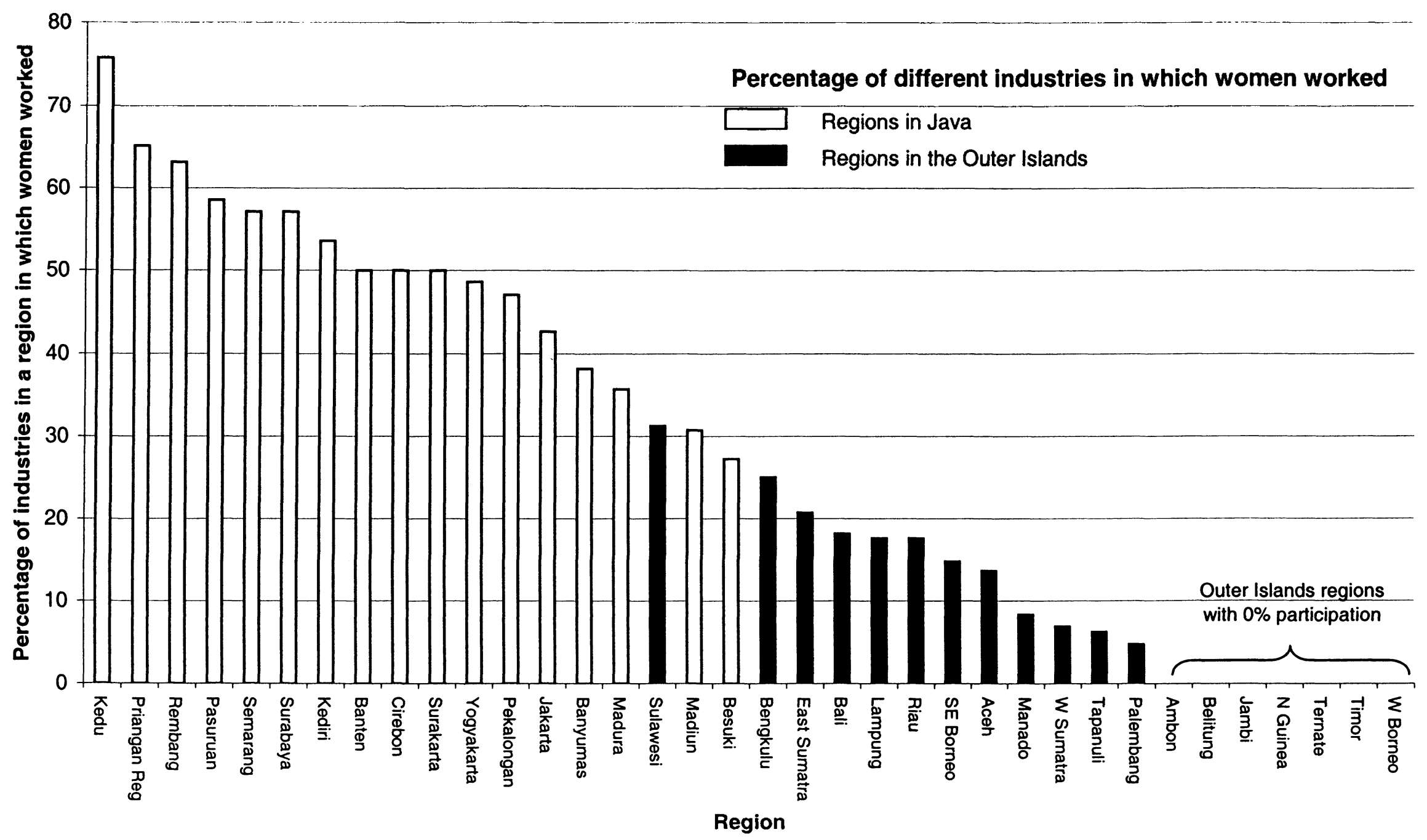


Figure 4: Participation of Indigenous Women in Industrial Labor by Industry*

(1918-1924)

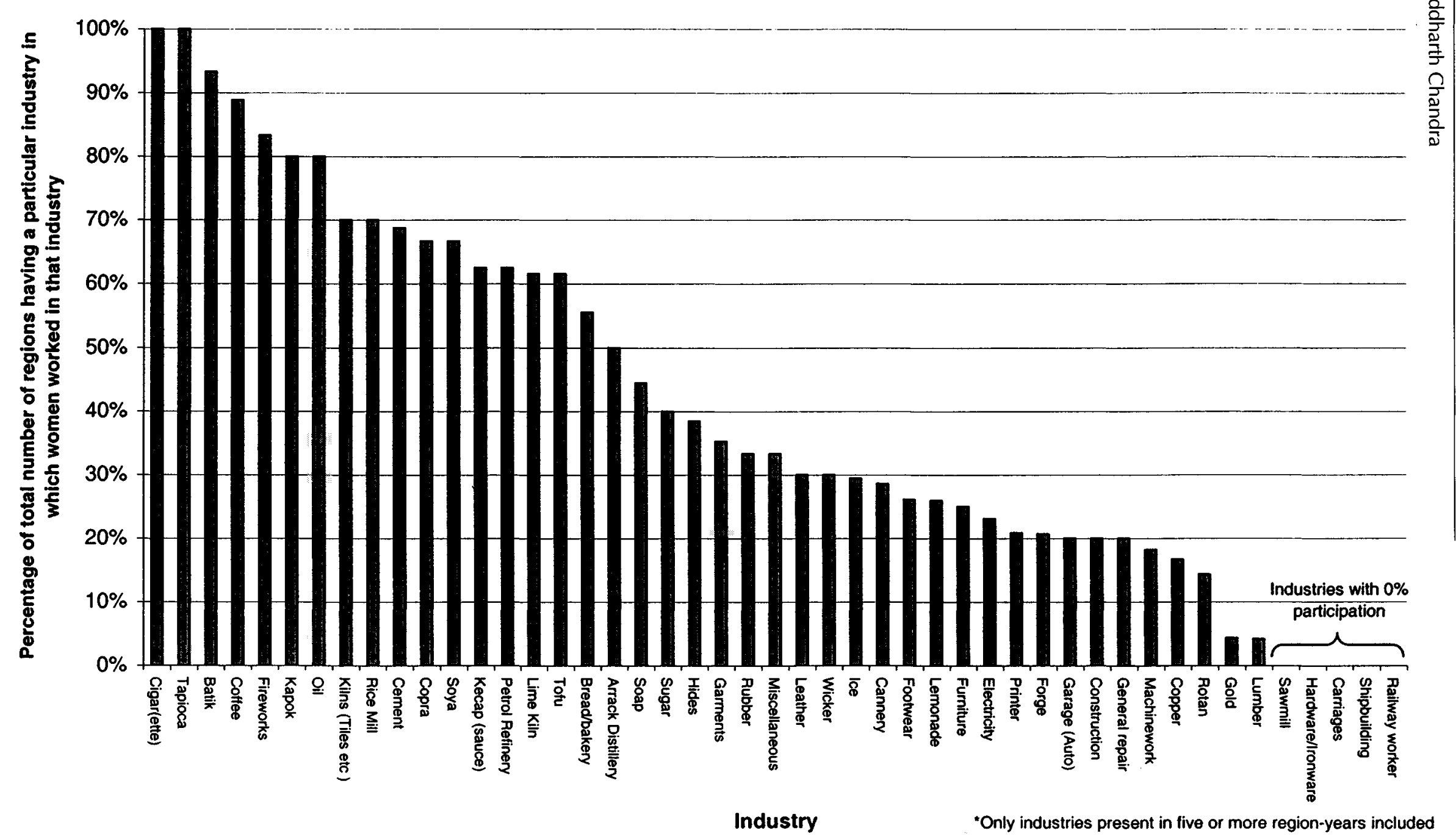


interesting concentrations of female industrial labor in the Netherlands Indies in the late 1910 s and early $1920 \mathrm{~s}^{34}$ The role of women within these concentrations will be discussed.

\section{Sectoral and Occupational Specialization}

While women clearly played a smaller role than men in industry in the Netherlands Indies, their presence was disproportionately frequent in a few sectors across regions. Figure 4 shows the sectors in which female labor had the broadest geographic representation. These include the cigar/cigarette, batik, and kapok sectors. ${ }^{35}$ The reasons for this presence are in many cases immediately apparent. For example, the manufacture of batik has, in a number of regions of Indonesia, been a predominantly female activity, and the role of women in the manufacture of batik has been accepted for centuries. ${ }^{36}$ Similarly, the kapok factories employed women to separate the kapok seed hairs from the seed to yield the soft fibrous stuffing used for pillows and furnishings. ${ }^{37}$ The process of cigar production involved female labor, especially at the grading and curing stages for cigar wrapper leaf. Specialization of tasks was, therefore, key to determining where and to what degree women were represented in industry.

A summary of the sectors in which female labor was dominant provides another interesting insight. Table 4 (below) shows the industries in which, for at least two regions, a large majority of workers were women. Most of these industries were based directly on the primary (and, in most cases, agricultural) sector and, with the exception of the building materials (gravel etc.) sector, they involved less physically demanding kinds of work.

\footnotetext{
${ }^{34}$ See also ibid, p. 62.

35 Although they were in some instances very different industries, the cigar and cigarette industries were treated as one because, in some residencies, the data for them were presented as one industry.

${ }^{36}$ For specific mention of this phenomenon, see ibid, p. 62.

${ }^{37}$ Kapok is also called Java Cotton. The kapok tree produces a fiber from its seed hair that was used to stuff pillows and upholstery. The seed of the kapok fruit was used to extract oil or was sold as seed-cake. Marguerite Schenkhuizen provides this vivid recollection of the process from her childhood days in the Netherlands Indies:
}

First, a group of women ... would open the ripe, dry kapok fruit by hand, one by one, pull the downy kapok from the inner core and throw it, seeds and all, on a pile .... the soft fluff would fill the air as soon as they started beating the pile with a stick with cross-bars attached in a form similar to a rake. They did this to separate the seeds from the down and to fluff up the kapok.

Marguerite Schenkhuizen, Memoirs of an Indo Woman: Twentieth Century Life in the East Indies and Abroad, ed. and trans. Lizelot Stout van Balgooy, Monographs in International Studies, Southeast Asia Series, no. 92 (Athens: Ohio University Center for International Studies, 1993), pp. 8-9. 
Table 4: Sectors with Highest Presence of Women

\begin{tabular}{|c|c|c|c|c|c|}
\hline \multicolumn{6}{|c|}{ Sectors with $100 \%$ female labor by skill level in at least two regions for at least one year } \\
\hline \multicolumn{2}{|c|}{ Unskilled } & \multicolumn{2}{|c|}{ Skilled } & \multicolumn{2}{|c|}{ Skilled and Unskilled } \\
\hline Sector & No. of Regions & Sector & No. of Regions & Sector & No. of Regions \\
\hline Cigar(ette) & 4 & Batik & 3 & Batik & 3 \\
\hline Batik & 2 & Bread & 2 & Krupuk & 2 \\
\hline Krupuk & 2 & Cigar(ette) & 2 & & \\
\hline Fireworks & 2 & Krupuk & 2 & & \\
\hline \multicolumn{6}{|c|}{$\begin{array}{c}\text { Sectors with at least } 75 \% \text { female labor by skill level in at least two regions for at least one } \\
\text { year }\end{array}$} \\
\hline \multicolumn{2}{|c|}{ Unskilled } & \multicolumn{2}{|c|}{ Skilled } & \multicolumn{2}{|c|}{ Skilled and Unskilled } \\
\hline Sector & No. of Regions & Sector & No. of Regions & Sector & No. of Regions \\
\hline Cigar(ette) & 7 & Batik & 8 & Batik & 7 \\
\hline Batik & 5 & Cigar(ette) & 5 & Cigar(ette) & 6 \\
\hline Kapok & 4 & Bread & 2 & Kapok & 2 \\
\hline Coffee & 3 & Krupuk & 2 & Krupuk & 2 \\
\hline Krupuk & 3 & & & Rice & 2 \\
\hline Fireworks & 2 & & & Bld. Mat. & 2 \\
\hline Bld. Mat. & 2 & & & & \\
\hline Rice & 2 & & & & \\
\hline
\end{tabular}

A related but different phenomenon is occupational/skill segregation. To capture this, an index of occupational/skill segregation was computed. 38 This index is the proportion of male workers who would have to be reallocated across skill levels to make their distribution (in percentage terms) across skill levels exactly match that of female workers. A value of 1 indicates complete segregation, in which case all (100 percent) men would have to be shifted. ${ }^{39} \mathrm{~A}$ value of 0 indicates that the distribution of men across skill levels is identical ( 0 percent would have to be shifted) to that of women.

Two sets of segregation indices were computed. The first included Chinese (all male) labor and the foremen category, in neither of which any women worked. In

38 See Otis D. Duncan and Beverly Duncan, "A Methodological Analysis of Segregation Indexes," American Sociological Review, 20 (1955): 210-217. This index has been widely used since. See, for example, Edward Gross, "Plus ça Change ... : The Sexual Structure of Occupations over Time," Social Problems 15 (1968): 198-208, pp. 201-202; and Goldin, Understanding the Gender Gap, p. 75. A problem with this index is the equal weight given to each occupation independently of its share in total labor. For a modified index that overcomes these problems but provides results similar to those of the Duncan index, see Jacques G. Silber, "On the Measurement of Employment Segregation," Economics Letters, 30 (1989): 237-243.

39 This would happen, for example, if all (100 percent) female workers were ervaren werklieden, and all male workers were gewone koelies, or vice versa. 
general, we would expect occupational/skill segregation between men and women to be higher in this case, because some women would have to be reallocated to the foremen category in order for the distribution of women to become identical to that of men. The second index was a variant of the first and excluded the Chinese and foremen categories. Table 5 (below) shows, by industry, the two segregation indices, one computed with Chinese male labor and foremen, and one without them. The results show no strong relationship between female labor intensity and segregation. ${ }^{40}$

Segregation indices are "skill-neutral" in the sense that they do not reveal whether women were segregated into low- or highly skilled occupations relative to their male counterparts. Therefore, a third and related index of skill-bias was also computed. ${ }^{41}$ This measure represents the proportion of women who would have to be promoted from the gewone koelies class to the ervaren werklieden class in order to match the proportions of men in the two classes. If the index is negative, women would have to be promoted, and if it is positive, women would have to be demoted to achieve equal proportions of women relative to men. In short, a positive value of this index reflects skill-oriented segregation for women, while a negative value reflects an unskilled orientation in female segregation. The results are shown in Table 6 (below). First, in only seven of the forty-four sectors did the skill-sensitive index indicate that women were more heavily represented as skilled labor relative to men. The three most favorable among these were electricity, krupuk (chips), and stroop (treacle), of which only krupuk was also a female intensive sector (Table 4). Of the thirty-seven sectors for which the skill bias was in the unskilled direction for women, coffins, iodine, and weaving (the weaving of mats, etc.) were the most heavily so.

\section{Geographic Variations}

Geographic variations in participation are another interesting characteristic of female industrial labor in the late colonial Netherlands Indies. Table 7 (below) contains a summary of the participation of women by industry across the Netherlands Indies. The means and ranges of female labor as a fraction of total labor across industrial establishments are presented Columns 3-5 of Table 7. Residencies in Java and Madura show substantially higher participation than do those of the Outer Islands.

In terms of regional breadth, Figure 3 shows, by region, the percentage of industries in which women worked in at least one establishment in one year. With the exception of Kedu, this percentage was less than 70 percent for all regions. In a phenomenon that parallels the results shown in Tables $2 b-c, 3 b-c$, and 7 , the residencies of Java and Madura show a greater breadth of industries with female involvement.

A summary of the regions in which female labor was dominant in some sectors provides another interesting insight. Table 8 (below) shows the regions in which, for at least two sectors, a large fraction of workers were women. Interestingly, even though

\footnotetext{
${ }^{40}$ In other words, industries in which a large proportion of workers were women were in some cases highly segregated and, in others, not highly segregated. There was no statistical correlation between female labor intensity and segregation.

${ }^{41}$ For this exercise, Chinese workers and foremen were excluded.
} 
Table 5: Occupational Gender Segregation by Sector

\begin{tabular}{|c|c|c|c|c|c|}
\hline \multicolumn{3}{|c|}{ Without Chinese } & \multicolumn{3}{|c|}{ With Chinese } \\
\hline Sector & $\begin{array}{c}\text { Number of } \\
\text { Observations } \\
\star \star \star\end{array}$ & $\begin{array}{c}\text { Segregation } \\
\text { Index }\end{array}$ & Sector & $\begin{array}{c}\text { Number of } \\
\text { Observations }\end{array}$ & $\begin{array}{c}\text { Segregation } \\
\text { Index }\end{array}$ \\
\hline Electric & 6 & 0.56 & Electric & 6 & 0.62 \\
\hline Furniture & 12 & 0.49 & Furniture & 12 & 0.57 \\
\hline Hide & 10 & 0.43 & Auto & 6 & 0.50 \\
\hline lodine & 6 & 0.42 & Arak & 5 & 0.48 \\
\hline Arak & 5 & 0.41 & lodine & 6 & 0.47 \\
\hline Auto & 6 & 0.40 & Hide & 10 & 0.46 \\
\hline Bread $^{\star}$ & 62 & 0.37 & Bread $^{*}$ & 62 & 0.41 \\
\hline Coffins & 7 & 0.32 & Cans & 12 & 0.36 \\
\hline Footwear & 8 & 0.31 & Krupuk* & 9 & 0.35 \\
\hline Cans & 12 & 0.31 & Coffins & 7 & 0.35 \\
\hline Printer & 22 & 0.30 & $\begin{array}{l}\text { Wung. } \\
\text { (bamb) }\end{array}$ & 7 & 0.34 \\
\hline $\begin{array}{l}\text { Wring. } \\
\text { (bamb) }\end{array}$ & 7 & 0.30 & Rice & 48 & 0.34 \\
\hline Metalwork & 8 & 0.29 & Fodder & 8 & 0.34 \\
\hline $\begin{array}{r}\text { Work } \\
\text { (mech.) }\end{array}$ & 5 & 0.29 & Printer & 22 & 0.34 \\
\hline Krupuk* & 9 & 0.28 & Ice & 24 & 0.33 \\
\hline Lemonade & 25 & 0.26 & Soap & 30 & 0.32 \\
\hline Leather & 6 & 0.26 & Work (mech.) & 5 & 0.31 \\
\hline Ice & 24 & 0.26 & Preserves & 7 & 0.31 \\
\hline Stroop & 5 & 0.26 & Lemonade & 25 & 0.31 \\
\hline Preserves & 7 & 0.26 & Metalwork & 8 & 0.31 \\
\hline Construction & 6 & 0.26 & Stroop & 5 & 0.30 \\
\hline Cement & 27 & 0.25 & Footwear & 8 & 0.30 \\
\hline Fodder & 8 & 0.25 & Cement & 27 & 0.30 \\
\hline Soap & 30 & 0.24 & Construction & 6 & 0.30 \\
\hline Tiles & 84 & 0.23 & Soya & 6 & 0.28 \\
\hline Batik* & 61 & 0.21 & Leather & 6 & 0.27 \\
\hline Apparel & 16 & 0.20 & Petrol Ref. & 12 & 0.26 \\
\hline Rice & 48 & 0.19 & Tiles & 84 & 0.25 \\
\hline Soya & 6 & 0.19 & Coffee & 24 & 0.25 \\
\hline Petrol Ref. & 12 & 0.17 & Batik* & 61 & 0.24 \\
\hline Oil & 49 & 0.17 & Apparel & 16 & 0.24 \\
\hline Chalk & 54 & 0.16 & Oil & 49 & 0.23 \\
\hline Bld. Mat.* & 8 & 0.16 & Bld. Mat. & 8 & 0.23 \\
\hline Fireworks* & 18 & 0.15 & Chalk & 54 & 0.22 \\
\hline Cigar* & 77 & 0.15 & Cigar* & 77 & 0.22 \\
\hline Coffee & 24 & 0.15 & Tapioca & 14 & 0.21 \\
\hline Tahu & 23 & 0.14 & Cassava & 5 & 0.20 \\
\hline Cassava & 5 & 0.14 & Tahu & 23 & 0.20 \\
\hline Tapioca & 14 & 0.09 & Copra & 13 & 0.19 \\
\hline Chemical & 8 & 0.07 & Kapok* & 40 & 0.16 \\
\hline Kapok* & 40 & 0.06 & Fireworks ${ }^{\star}$ & 18 & 0.16 \\
\hline Mining & 10 & 0.04 & Kecap & 7 & 0.11 \\
\hline Kecap & 7 & 0.03 & Chemical & 8 & 0.11 \\
\hline Copra & 13 & 0.02 & Mining & 10 & 0.08 \\
\hline
\end{tabular}

*Female-labor-intensive sector (from Table 4).

**This is the number of different region years for which data in a particular industry were provided. 
Table 6: Female Skill Bias by Industry

\begin{tabular}{|c|c|c|c|c|c|}
\hline Sector & $\begin{array}{c}\text { No. of } \\
\text { Observations }{ }^{* *}\end{array}$ & $\begin{array}{c}\text { Index of Skill } \\
\text { Bias } \\
\end{array}$ & Sector & $\begin{array}{c}\text { No. of } \\
\text { Observations }{ }^{\star *}\end{array}$ & $\begin{array}{c}\text { Index of Skill } \\
\text { Bias }\end{array}$ \\
\hline Electric & 6 & 0.35 & Tapioca & 14 & -0.09 \\
\hline Krupuk $^{*}$ & 9 & 0.23 & Rice & 48 & -0.09 \\
\hline Stroop & 5 & 0.14 & Lemonade & 25 & -0.10 \\
\hline Bld. Mat.* & 8 & 0.09 & Work (mech.) & 5 & -0.10 \\
\hline Metalwork & 8 & 0.03 & Leather & 6 & -0.10 \\
\hline Copra & 13 & 0.01 & Ice & 24 & -0.10 \\
\hline Cigar* & 77 & 0.01 & Lime Kiln & 54 & -0.10 \\
\hline Printer & 22 & -0.01 & Auto & 6 & -0.11 \\
\hline Tahu & 23 & -0.01 & Hide & 10 & -0.11 \\
\hline Soap & 30 & -0.01 & Furniture & 12 & -0.12 \\
\hline Construction & 6 & -0.01 & Apparel & 16 & -0.12 \\
\hline Cassava & 5 & -0.02 & Coffee & 24 & -0.14 \\
\hline Kecap & 7 & -0.02 & Preserves & 7 & -0.15 \\
\hline Mining & 10 & -0.04 & Soya & 6 & -0.17 \\
\hline Kapok* & 40 & -0.05 & Petrol Ref. & 12 & -0.17 \\
\hline Footwear & 8 & -0.05 & Cement & 27 & -0.17 \\
\hline Tiles & 84 & -0.06 & Arak & 5 & -0.17 \\
\hline Oil & 49 & -0.06 & Bread $^{*}$ & 62 & -0.23 \\
\hline Fireworks $^{*}$ & 18 & -0.06 & Fodder & 8 & -0.25 \\
\hline Chemical & 8 & -0.07 & $\begin{array}{c}\text { Wvng. } \\
\text { (bamb) }\end{array}$ & 7 & -0.30 \\
\hline Cans & 12 & -0.08 & lodine & 6 & -0.31 \\
\hline Batik $^{*}$ & 61 & -0.08 & Coffin & 7 & -0.32 \\
\hline
\end{tabular}

*Female-labor-intensive sector (from Table 3).

${ }^{* *}$ This is the number of different region years for which data in a particular industry were provided. 
Table 7: Mean and Range of Women as a Fraction of Total Labor in Industries by Region, 1918-1924

\begin{tabular}{|l|c|c|c|c|}
\hline \multirow{2}{*}{ Region } & Number of & Mean & \multicolumn{2}{c|}{ Range } \\
\cline { 4 - 5 } & Observations & & Low & High \\
\hline Palembang & 65 & 0.00 & 0 & 0.00 \\
\hline Riau & 49 & 0.01 & 0 & 0.12 \\
\hline Bengkulu & 41 & 0.01 & 0 & 0.26 \\
\hline South East Borneo & 53 & 0.01 & 0 & 0.18 \\
\hline West Sumatra & 117 & 0.01 & 0 & 1.00 \\
\hline East Sumatra & 99 & 0.01 & 0 & 0.50 \\
\hline Tapanuli & 45 & 0.02 & 0 & 0.50 \\
\hline Banten & 35 & 0.03 & 0 & 0.17 \\
\hline Besuki & 130 & 0.04 & 0 & 0.85 \\
\hline Sulawesi & 27 & 0.04 & 0 & 0.56 \\
\hline Madura & 33 & 0.04 & 0 & 0.39 \\
\hline Jakarta & 264 & 0.05 & 0 & 0.65 \\
\hline Lampung & 46 & 0.06 & 0 & 1.00 \\
\hline Cirebon & 123 & 0.08 & 0 & 0.73 \\
\hline Yogyakarta & 166 & 0.09 & 0 & 0.95 \\
\hline Bali & 23 & 0.09 & 0 & 0.43 \\
\hline Pekalongan & 124 & 0.11 & 0 & 0.95 \\
\hline Surakarta & 65 & 0.11 & 0 & 0.52 \\
\hline Pasuruan & 168 & 0.12 & 0 & 0.89 \\
\hline Madiun & 105 & 0.13 & 0 & 1.00 \\
\hline Surabaya & 282 & 0.13 & 0 & 1.00 \\
\hline Kedu & 144 & 0.14 & 0 & 1.00 \\
\hline Semarang & 228 & 0.14 & 0 & 0.77 \\
\hline Priangan & 264 & 0.14 & 0 & 1.00 \\
\hline Rembang & 118 & 0.14 & 0 & 1.00 \\
\hline Banyumas & 124 & 0.14 & 0 & 1.00 \\
\hline Kediri & 142 & 0.15 & 0 & 0.69 \\
\hline & & & & \\
\hline & & 0 & 0 & 0 \\
\hline
\end{tabular}

"Mean calculated from observations, where each observation is one industry in one year. 
Table 8: Regions with Highest Presence of Women

\begin{tabular}{|c|c|c|c|c|c|}
\hline \multicolumn{6}{|c|}{ Regions with $100 \%$ female labor by skill level in at least two sectors } \\
\hline \multicolumn{2}{|c|}{ Unskilled } & \multicolumn{2}{|c|}{ Skilled } & \multicolumn{2}{|c|}{ Skilled and Unskilled } \\
\hline Region & No. Sectors & Region & No. Sectors & Region & No. Sectors \\
\hline Kedu & 4 & Banyumas & 4 & Banyumas & 5 \\
\hline Surabaya & 4 & Kedu & 2 & Priangan & 2 \\
\hline Banyumas & 3 & Madiun & 2 & Surabaya & 2 \\
\hline Priangan & 3 & Priangan & 2 & & \\
\hline Lampung & 2 & Surabaya & 2 & & \\
\hline Rembang & 2 & & & & \\
\hline \multicolumn{6}{|c|}{ Regions with $75 \%$ female labor by skill level in at least two sectors } \\
\hline \multicolumn{2}{|c|}{ Unskilled } & \multicolumn{2}{|c|}{ Skilled } & \multicolumn{2}{|c|}{ Skilled and Unskilled } \\
\hline Region & No. Sectors & Region & No. Sectors & Region & No. Sectors \\
\hline Priangan & 7 & Priangan & 6 & Banyumas & 6 \\
\hline Pasuruan & 5 & Banyumas & 4 & Priangan & 6 \\
\hline Banyumas & 4 & Yogyakarta & 3 & Surabaya & 5 \\
\hline Kedu & 4 & Surabaya & 3 & Pekalongan & 4 \\
\hline Rembang & 4 & Kedu & 2 & Yogyakarta & 3 \\
\hline Semarang & 4 & Madiun & 2 & Pasuruan & 3 \\
\hline Surabaya & 4 & Pasuruan & 2 & Lampung & 2 \\
\hline Madiun & 3 & Rembang & 2 & Madiun & 2 \\
\hline Pekalongan & 3 & & & Rembang & 2 \\
\hline Cirebon & 2 & & & & \\
\hline Yogyakarta & 2 & & & & \\
\hline Lampung & 2 & & & & \\
\hline
\end{tabular}

the major urban centers of Java (Jakarta, Cirebon, Semarang, and Surabaya, for example) were home to larger numbers of different industries, with the exception of Surabaya (and Priangan [which includes Bandung], though it is more appropriately classified as a rural residency because of its large and mostly rural area), they do not systematically appear among the regions in which many industries had high female representation. It is the more rural residencies of Java-including Priangan, Banyumas, and $\mathrm{Kedu}$-that stand out for female-intense industries. ${ }^{42}$ The only Outer Island residency that had more than one female-intense sector was Lampung. ${ }^{43}$

\footnotetext{
42 While Surabaya also appears in this list, it should be noted that, by virtue of the fact that there were more different kinds of industries in Surabaya, one would expect a larger number of different industries to have high female representation.

${ }^{43}$ By virtue of its proximity to Java, Lampung may have been similar in some respects to a residency on Java, notably in such aspects as the ethnic mix of its population (and the number of Javanese as a percentage of total population in particular) or the diversity of its economy. Unlike residencies on Java, however, Lampung was very sparsely populated, at only eight persons per square kilometer. For data on population density in the Outer Islands, see Peter Boomgaard and Abrahamine J. Gooszen, Changing Economy in Indonesia: Population Trends 1795-1942, in Changing Economy in Indonesia series, vol. 11 (Amsterdam: Royal Tropical Institute, 1991), Table 22, p. 242.
} 


\section{Correlates of the Likelihood of Presence of Female Labor}

In order to separate out the contributions of location and other factors to the likelihood of the presence of female labor in industry, statistical models were estimated that enable the researcher to measure the effect of one variable while controlling for the effects of other variables.44 Not surprisingly, these models confirmed that location, industry, and scale of industry in a region are all statistically significant correlates of the presence of women. For example, the regional contributions to the likelihood of female presence showed that, conditional on the other variables, the likelihood of female participation was in general higher in the residencies of Java than it was in the residencies of the Outer Islands. There are good reasons for this. The economies of Java differed from those of the Outer Islands. The former were more labor intensive and included the manufacture of numerous small consuner goods. The economies of the Outer Islands, especially at the time under consideration, were relatively young economies, powered primarily by male labor imported from China or Java. ${ }^{45}$ Because of the physically demanding nature of the dominant activities (natural-resource extraction, such as mining and timber, for example) in a number of these economies, it is not surprising that relatively few openings in industry were available to women.

In terms of sectoral presence, the industries in which women were likely to be present were, by and large, light industry related to the manufacture of primary products. The work of female labor, as described earlier, involved the lighter and more specialized tasks of sorting and/or processing agricultural produce. The garages, forges, ice factories, and construction establishments were much less likely to have female laborers than were tapioca, kapok, or coffee processing establishments.

\section{Correlates of Female Labor as a Fraction of Total Labor}

The discussion above focused on the breadth of female participation in industrial production. In this section, I turn to the analysis of the depth of participation within particular regions. In other words, what percentage of the industrial labor force of a particular region was female, and what were the correlates of this percentage? To analyze this issue, additional statistical analyses were conducted. In particular, I tested whether, across the residencies of the Netherlands East Indies, the fraction of industrial labor represented by females was correlated with the average wage earned by females, the average wage earned by all labor, the population density of the region,

\footnotetext{
${ }^{44}$ In this case, the methods used were logistic regressions to model the absence or presence of women.

45 The East Coast of Sumatra (Oostkust van Sumatra), or East Sumatra for short, for example, had only been "discovered" in the second half of the nineteenth century, when Jacobus Nienhuys arrived at the Sultanate of Deli and established the Deli Maatschappij, the first Dutch tobacco company in the area. For a description of the area prior to that time, see John Anderson, Mission to the East Coast of Sumatra in 1823 (Kuala Lumpur: Oxford University Press, 1971). By the early twentieth century, East Sumatra had made the transition from being a major producer of cigar wrapper tobacco to being a major producer of rubber, competing even with the British plantations of Malaya. See Thee Kian-wie, Plantation Agriculture and Export Growth: An Economic History of East Sumatra, 1863-1942 (Jakarta: National Institute of Economic and Social Research [LEKNAS-LIPI], 1977). For related work on the development of East Sumatra, see Karl J. Pelzer, Planter and Peasant: Colonial Policy and the Agrarian Struggle in East Sumatra, 1863-1947 ('sGravenhage: Martinus Nijhoff, 1978); and Ann Laura Stoler, Capitalism and Confrontation in Sumatra's Plantation Belt, 1870-1979 (New Haven: Yale University Press, 1985), Chapters 2 and 3.
} 
the industrial diversity of a region as measured by the number of different industries recorded over the time period in question, and whether or not the region was located in Java and Madura. ${ }^{46}$

Tables 9a and 9b (below) show numerical and rank correlations of female labor as a fraction of total labor with the aforementioned variables. ${ }^{47}$ The correlations (Column 1 of Tables 9a and 9b) with population density, industrial diversity, and location in Java and Madura are positive and statistically significant. ${ }^{48}$ They are negative and statistically significant for the measures of wage, both female and overall. These correlations show that women were more deeply involved in industrial production in residencies with low wages, high population densities, high levels of industrial diversity, and located in Java and Madura. Of course, the results do not necessarily imply any causal relationship between the fraction of labor female and these variables, because they are also correlated with each other. This can create problems of interpretation. ${ }^{49}$ There are ways to minimize these problems. In the context of

\footnotetext{
46 The reasons for the choice of these variables will become apparent in a later section. A notable exception in the regional analysis is Bali, which, although it is an "Outer Island," shows a high level of participation. Because of its geographic and cultural proximity to Java, however, Bali has occasionally been classified as an "inner" island, along with Java and Madura.

${ }^{47}$ Correlation coefficients range between -1 and 1 . A value of 1 indicates perfect (positive) correlation. In this case, higher values of one variable (the fraction of labor female, say) across residencies are exactly matched by higher values of the variable with which its correlation is being measured (say the industrial diversity of those residencies). A value of 0 indicates no correlation, and a value of -1 indicates perfectly negative correlation, in which case, higher values of one variable across residencies are exactly matched by lower values for the variable with which its correlation is being measured. Correlations can be computed using raw numbers such as the fraction of labor female across regions and the industrial diversity of regions (numerical correlations), or by using ranks of regions according to these variables (rank correlations). Numerical correlations tend to be more heavily influenced by outliers, or observations that have extremely high or low values for one or both variables.

48 In this case, statistical significance is an indicator of the likelihood that the true correlation, represented by the estimates in the tables, is in fact 0 . Statistical significance is measured using $p$-values, the middle number in each cell of Tables $9 a$ and $9 b$. The lower that number is, the less likely is the actual correlation to be 0 . Small $p$-vlaues, therefore, indicate strong statistical evidence of correlation.

${ }^{49}$ For example, industrial diversity and population density are highly correlated with each other (Column 4, Row 5 in Tables $9 \mathrm{a}$ and $9 \mathrm{~b}$ ). Does this mean that density leads to diversity which leads to greater female participation? Or does it mean that diversity leads to density which leads to greater female participation? Or, does female participation drive density (unlikely) and/or diversity (possible)? Questions of causality plague statistical analysis in the social sciences, and often, at some point, it is up to the researcher to create consistent and meaningful interpretations of the results.
} 
128 Siddharth Chandra

Table 9a: Numerical Correlations between Female Economic Role Variables and Other General Economic Variables at the Residency Level

\begin{tabular}{|c|c|c|c|c|c|c|}
\hline & $\begin{array}{l}\text { Fraction of } \\
\text { Labor Force } \\
\text { Female }\end{array}$ & $\begin{array}{l}\text { Real Wage } \\
\text { Female }\end{array}$ & $\begin{array}{l}\text { Real Wage } \\
\text { All }\end{array}$ & $\begin{array}{l}\text { Population } \\
\text { Density }\end{array}$ & $\begin{array}{l}\text { Industrial } \\
\text { Diversity }\end{array}$ & $\begin{array}{l}\text { In Java and } \\
\text { Madura }\end{array}$ \\
\hline $\begin{array}{l}\text { Fraction of } \\
\text { Labor Force } \\
\text { Female }\end{array}$ & $\begin{array}{r}1.000 \\
35 \\
\end{array}$ & & & & & \\
\hline $\begin{array}{l}\text { Real Wage } \\
\text { Female }\end{array}$ & $\begin{array}{c}-0.750 \\
<.0001 \\
28 \\
\end{array}$ & $\begin{array}{r}1.000 \\
28 \\
\end{array}$ & & & & \\
\hline $\begin{array}{l}\text { Real Wage } \\
\text { All }\end{array}$ & $\begin{array}{c}-0.437 \\
0.009 \\
35 \\
\end{array}$ & $\begin{array}{c}0.752 \\
<.0001 \\
29 \\
\end{array}$ & $\begin{array}{r}1.000 \\
37 \\
\end{array}$ & & & \\
\hline $\begin{array}{l}\text { Population } \\
\text { Density }\end{array}$ & $\begin{array}{c}0.844 \\
<.0001 \\
35 \\
\end{array}$ & $\begin{array}{c}-0.773 \\
<.0001 \\
29 \\
\end{array}$ & $\begin{array}{c}-0.377 \\
0.021 \\
37 \\
\end{array}$ & $\begin{array}{r}1.000 \\
37 \\
\end{array}$ & & \\
\hline $\begin{array}{l}\text { Industrial } \\
\text { Diversity }\end{array}$ & $\begin{array}{c}0.645 \\
<.0001 \\
35\end{array}$ & $\begin{array}{c}-0.309 \\
0.103 \\
29\end{array}$ & $\begin{array}{c}-0.308 \\
0.064 \\
37\end{array}$ & $\begin{array}{c}0.613 \\
<.0001 \\
37\end{array}$ & $\begin{array}{c}1.000 \\
37\end{array}$ & \\
\hline $\begin{array}{l}\text { In Java and } \\
\text { Madura }\end{array}$ & $\begin{array}{c}0.802 \\
<.0001 \\
35\end{array}$ & $\begin{array}{c}-0.761 \\
<.0001 \\
29\end{array}$ & $\begin{array}{c}-0.409 \\
0.012 \\
37\end{array}$ & $\begin{array}{c}0.849 \\
<.0001 \\
37\end{array}$ & $\begin{array}{c}0.628 \\
<.0001 \\
37\end{array}$ & $\begin{array}{c}1.000 \\
42 \\
\end{array}$ \\
\hline
\end{tabular}

The top number in each cell is the correlation coefficient. The middle number is the $p$-value for the hypothesis test of 0 -correlation (a low $p$-value, usually less than 0.05 , indicates statistical significance). The bottom number in each cell is the number of regional observations from which the correlations were computed. 
Table 9b: Rank Correlations between Female Economic Role Variables and Other General Economic Variables at the Residency Level

\begin{tabular}{|c|c|c|c|c|c|c|}
\hline & $\begin{array}{l}\text { Fraction of } \\
\text { Labor Force } \\
\text { Female }\end{array}$ & $\begin{array}{l}\text { Real Wage } \\
\text { Female }\end{array}$ & $\begin{array}{l}\text { Real Wage } \\
\text { All }\end{array}$ & $\begin{array}{l}\text { Population } \\
\text { Density }\end{array}$ & $\begin{array}{l}\text { Industrial } \\
\text { Diversity }\end{array}$ & $\begin{array}{l}\text { In Java and } \\
\text { Madura }\end{array}$ \\
\hline $\begin{array}{l}\text { Fraction of } \\
\text { Labor Force } \\
\text { Female }\end{array}$ & $\begin{array}{r}1.000 \\
35 \\
\end{array}$ & & & & & \\
\hline $\begin{array}{l}\text { Real Wage } \\
\text { Female }\end{array}$ & $\begin{array}{c}-0.745 \\
<.0001 \\
28 \\
\end{array}$ & $\begin{array}{r}1.000 \\
28 \\
\end{array}$ & & & & \\
\hline $\begin{array}{l}\text { Real Wage } \\
\text { All }\end{array}$ & $\begin{array}{c}-0.633 \\
<.0001 \\
35 \\
\end{array}$ & $\begin{array}{c}0.779 \\
<.0001 \\
29 \\
\end{array}$ & $\begin{array}{r}1.000 \\
37 \\
\end{array}$ & & & \\
\hline $\begin{array}{l}\text { Population } \\
\text { Density }\end{array}$ & $\begin{array}{c}0.830 \\
<.0001 \\
35\end{array}$ & $\begin{array}{c}-0.754 \\
<.0001 \\
29\end{array}$ & $\begin{array}{c}-0.556 \\
0.0004 \\
37\end{array}$ & $\begin{array}{c}1.000 \\
37\end{array}$ & & \\
\hline $\begin{array}{l}\text { Industrial } \\
\text { Diversity }\end{array}$ & $\begin{array}{c}0.747 \\
<.0001 \\
35 \\
\end{array}$ & $\begin{array}{c}-0.398 \\
0.033 \\
29 \\
\end{array}$ & $\begin{array}{c}-0.374 \\
0.022 \\
37 \\
\end{array}$ & $\begin{array}{c}0.680 \\
<.0001 \\
37 \\
\end{array}$ & $\begin{array}{r}1.000 \\
37 \\
\end{array}$ & \\
\hline $\begin{array}{l}\text { In Java and } \\
\text { Madura }\end{array}$ & $\begin{array}{r}0.818 \\
<.0001 \\
35 \\
\end{array}$ & $\begin{array}{c}-0.714 \\
<.0001 \\
29 \\
\end{array}$ & $\begin{array}{c}-0.603 \\
<.0001 \\
37 \\
\end{array}$ & $\begin{array}{c}0.803 \\
<.0001 \\
37 \\
\end{array}$ & $\begin{array}{c}0.672 \\
<.0001 \\
37 \\
\end{array}$ & $\begin{array}{r}1.000 \\
42 \\
\end{array}$ \\
\hline
\end{tabular}

The top number in each cell is the correlation coefficient. The middle number is the $p$-value for the hypothesis test of 0 -correlation (a low $p$-value, usually less than 0.05 , indicates statistical significance). The bottom number in each cell is the number of regional observations from which the correlations were computed. 
correlation analysis, one such method is the use of partial correlations. ${ }^{50}$ Table 10 shows partial numerical and rank correlations between the fraction of labor female and four of the five variables listed above. ${ }^{51}$ The partial correlation analysis reveals that high population density is correlated (numerically and by rank) with greater female participation even after controlling for the other variables. In addition, there is weaker evidence of correlation (rank only) between the real wage (negative) and industrial diversity (positive) and female participation in industry. These results will be discussed later.

Table 10: Partial Correlations between Proportion of Labor Female and Other General Economic Variables at the Residency Level

\begin{tabular}{|l|c|c|}
\hline \multirow{2}{*}{ Real Wage All } & \multicolumn{2}{|c|}{ Proportion of Labor Female } \\
\cline { 2 - 3 } & Numerical Correlation & Rank Correlation \\
& -0.181 & -0.339 \\
& 0.321 & 0.058 \\
& 35 & 35 \\
\hline Population Density & 0.498 & 0.403 \\
& 0.004 & 0.022 \\
& 35 & 35 \\
\hline Industrial Diversity & 0.242 & 0.427 \\
& 0.182 & 0.015 \\
& 35 & 35 \\
\hline In Java and Madura & 0.230 & 0.286 \\
& 0.205 & 0.113 \\
& 35 & 35 \\
\hline
\end{tabular}

* See note below Table 9a for explanation of numbers.

\section{A Brief Note on Wages for Female Industrial Labor}

Having studied the scope and depth of female involvement in industrial labor, I now move to a brief analysis of wages and movements in wages. The two aspects of wages analyzed are real wages for women, and a comparison of male and female wages. ${ }^{52}$ First, straight averages of the wages were computed. Next, statistical

${ }^{50}$ A partial correlation measures the correlation between two variables after "flushing out" the correlations of these variables with other potentially confounding variables. While this involves eliminating potentially valuable statistical information, one can be fairly confident that, if both the full and partial correlations between two variables are statistically significant and have the same sign (i.e., both positive or both negative), then the two variables are related to each other.

51 The fifth variable, the female wage, shows results that are very similar to those for the overall wage. For this reason, it is not included among the results.

52 The real wage is the inflation-adjusted wage. In order to compare wages over time and/or across regions, it is necessary to adjust the value of the wage to reflect differences in the purchasing power of money at different times and/or in different places. 
analyses of the wages were conducted using two different methods, which allowed for a comparison of male and female wages after controlling for factors such as skill level.

In order to analyze real wages, first the nominal wage was deflated by a price index to yield the real wage. ${ }^{53}$ This price index was obtained from a publication in the Changing Economy in Indonesia series. ${ }^{54}$ Then averages were computed for male, female, and combined real wages for the period 1918-1924. Tables 11a and 11b (below) contain these statistics by gender. ${ }^{55}$ They reveal that, on average, women earned approximately a third of the wage that men earned. In some respects, however, the numbers are not comparable, because the male average includes wages for the Chinese and foremen categories, which include no women. In order to control for such distorting effects, comparisons using two different statistical methods that control for such biases were also made. ${ }^{56}$ As might be expected, if we control for these distortions, the ratio of female to male wages rises, to approximately two-thirds. This analysis also shows the lack of any systematic correlation between the male-female wage differential and the variables analyzed in Table 9a. This demonstrates that, unlike female participation in the industrial labor market, which presented distinct patterns in relation to general geographic and economic variables, the male-female wage differential shows no such regularities.

53 The nominal wage is the wage prior to its adjustment for inflation. Adjustment for inflation is done by valuing the currency in terms of its purchasing power, generally in terms of a predetermined and representative basket of consumption goods. While a variety of statistics for this purpose exist (see the following footnote) for the late colonial Netherlands Indies, the only series that extend as far back at 1918 are series on the prices of rice. For this reason, in this study, a rice price index will be used to adjust the nominal wage.

54 See W. M. F. Mansvelt and P. Creutzberg, Changing Economy in Indonesia: Rice Prices, in Changing Economy in Indonesia series, vol. 4 (The Hague: Martinus Nijhoff, 1978), Table 1, pp. 43-47. For related series on price indices, see Department van Economische Zaken, Prijzen, Indexciffers en Wisselkoersen op Java 1913-1937. Mededeelingen van het Centraal Kantoor voor de Statistiek, no.146 (Batavia: Centraal Kantoor voor de Statistiek, 1938); W. L. Korthals Altes, Changing Economy in Indonesia: Prices (non-rice) 1814-1940, in Changing Economy in Indonesia series, vol. 15 (Amsterdam: Royal Tropical Institute, 1994), and J. J. Polak, The National Income of the Netherlands Indies, 1921-1989 (New York: Netherlands and Netherlands Indies Council, Institute for Pacific Relations, 1943). For years preceding 1921, the first year covered by Polak's series, it is standard practice to fall back on rice prices as an indicator of the cost of living. This index is, however, less accurate for regions in which rice was not a major article of consumption (especially some of the areas of the Outer Islands) than it is for Java.

55 Because high wages were reported separately from low wages only after 1920 (there are a few exceptions to this rule; for Riau, for example, some data in 1920 were provided as ranges too), care should be taken in interpreting the pre-1921 and post-1920 averages in the same way.

56 The methods were the Oaxaca decomposition and Polachek's comparison. The Oaxaca decomposition involves, first, the separate estimation, by group (male and female) of the contributions of individual and industry-specific characteristics of workers to the wage of workers in that group. Once this is done, it is possible to compute the portion of the difference in wages between the two groups that is not attributable to differences in individual or industry-specific characteristics. This residual portion of the wage difference is interpreted variously as "discrimination" or the effect of unmeasured but important variables. See Ronald Oaxaca, "Male-Female Wage Differentials in Urban Labor Markets," International Economic Review 9 (1973): 693-709, for use of this method. Polachek's comparison is simpler, involving as it does the straight comparison of wages for workers who are identical in all respects (individual or industry-specific), except the characteristic of interest (in this case gender). See Solomon Polachek, "Occupational Segregation and the Gender Wage Gap." 
132 Siddharth Chandra

Table 11a: Low Wage in Real Guilders, 1918-1924

\begin{tabular}{|c|c|c|c|}
\hline Year & Female & Male & All \\
\hline 1918 & 0.26 & 0.58 & 0.54 \\
\hline 1919 & 0.24 & 0.70 & 0.64 \\
\hline 1920 & 0.17 & 0.42 & 0.38 \\
\hline 1921 & 0.20 & 0.46 & 0.41 \\
\hline 1922 & 0.32 & 0.75 & 0.68 \\
\hline 1923 & 0.28 & 0.78 & 0.70 \\
\hline 1924 & 0.23 & 0.65 & 0.57 \\
\hline
\end{tabular}

Table 11b: High Wage in Real Guilders, 1918-1924

\begin{tabular}{|c|c|c|c|}
\hline Year & Female & Male & All \\
\hline 1918 & 0.26 & 0.58 & 0.54 \\
\hline 1919 & 0.24 & 0.70 & 0.64 \\
\hline 1920 & 0.17 & 0.42 & 0.38 \\
\hline 1921 & 0.34 & 0.83 & 0.73 \\
\hline 1922 & 0.43 & 1.37 & 1.22 \\
\hline 1923 & 0.41 & 1.46 & 1.28 \\
\hline 1924 & 0.32 & 1.08 & 0.94 \\
\hline
\end{tabular}

\section{Economics, Tradition, and Female Industrial Labor in the Late Colonial} Netherlands Indies

So far a characterization of female industrial labor across the Netherlands Indies in the late colonial era has been presented. I now return to discussion of the economic position of women in the context of the economic development of Indonesia and the prior work on female labor in the late colonial era. For the purpose of economic analysis, Indonesia has traditionally been and continues to be divided into two regions, namely Java and Madura, and the Outer Islands. These regions have been characterized by very different economic conditions-while Java and Madura are densely populated and therefore labor-abundant, the Outer Islands are sparsely populated. ${ }^{57}$ While Java and Madura are relatively scarce in natural resources, the Outer Islands have traditionally produced a wealth of mineral resources, from oil to tin. ${ }^{58}$ Agriculture in Java has been closely intertwined with the labor-intensive sawah

57 See Hans Gooszen, A Demographic History of the Indonesian Archipelago, 1880-1942 (Singapore: Institute of Southeast Asian Studies, 2000) for a historical discussion of demographic diversity in Indonesia.

58 For a discussion of this difference and its role in the development of modern Indonesia, see Howard Dick, Vincent J. H. Houben, J. Thomas Lindblad, and Thee Kian Wie, The Emergence of a National Economy: An Economic History of Indonesia, 1800-2000 (Sydney: Allen and Unwin, 2002). 
(wet rice) system of cultivation, and even "plantation" crops like indigo (no longer under cultivation) and sugar have likewise been labor-intensive. ${ }^{59}$ Outside Java, plantation agriculture-from the farming of tobacco and rubber to the more recently dominant kelapa sawit (oil of palm) agriculture-has been more extensive, involving lower ratios of labor to land. While the frontier regions of the Outer Islands were still being opened to economic exploitation during the colonial era (and in some areas continue to be so developed), the frontier in Java and Madura had been more or less fully opened by the late nineteenth century. ${ }^{60}$ As the population of the region continued to grow, these economies became increasingly well-positioned to gain from producing labor-intensive goods that were consumer-oriented; a large and relatively abundant and cheap labor pool stood at the ready to produce and then to consume the fruits of this very production if it was not destined for export markets. It was this niche of the labor market for which the female labor force was particularly well-suited. This is not to say that women were completely absent from the Outer Islands. The formal sectors of those economies had just not developed and diversified enough to create a significant demand for the goods that female labor was considered to be particularly well-suited to produce. In this respect, the contrast between Java and Madura and the Outer Islands in the late colonial era provides a fascinating snapshot of the economic development of the Netherlands Indies. To the extent that absorption of female labor is an indicator of stages of development, Java and Madura were several strides ahead of the Outer Islands at this time. Whether or not this is still the case almost a century later would be an interesting question to explore. ${ }^{61}$

I now turn to a few hypotheses laid out in the literature, and specifically by Elsbeth Locher-Scholten, on the economic position of women in the Netherlands Indies. These include the proposed correlations between population density, prosperity, and economic diversity on one hand, and the role of female labor on the other. In LocherScholten's work, the findings are somewhat ambiguous. For example, while she suggests that there should be a positive relationship between population density and the role of women in the economy, she finds that this relationship does not exactly hold, especially for economies that are very densely or sparsely populated. Because of her focus on Java and Madura, however, there are relatively few regions at which to look, and there is relatively little variation in population density across the regions. Patterns are likely to be obscured for these two reasons. By introducing the regions of the Outer Islands, in which population densities were, by and large, substantially

\footnotetext{
${ }^{59}$ See Siddharth Chandra and Timothy J. Vogelsang, "Change and Involution in Sugar Production in Cultivation System Java," Journal of Economic History 59 (1999): 885-911, for a discussion of increasing labor intensity and technological change in agriculture in Java in the nineteenth century.

${ }^{60}$ See Clifford Geertz, Agricultural Involution: The Processes of Ecological Change in Indonesia (Berkeley: University of California Press, 1970).

61 There is a substantial literature in economics, going back at least three decades, on the economic role of women at different stages of economic development. See, for example, Esther Boserup, Women's Role in Economic Development (London: George Allen and Unwin, 1970). In that book, Boserup argues that the process of economic modernization results in the replacement of traditional sectors, in which women play an important economic role, with modern sectors, in which the role of women is diminished. As a result, the process of modernization results in the economic alienation of women. One finding of this study (discussed above), that the representation of women in industry was substantially weaker than that of women in agriculture, is consistent with Boserup's thesis. Whether or not and the extent to which economic activity in the industrial sector replaces economic activity in the agricultural sector, however, is still open to question.
} 
134 Siddharth Chandra

lower, it is possible to statistically test for such relationships on a larger sample of regions with greater variation in population density. ${ }^{62}$

Tables $9 \mathrm{a}$ and $9 \mathrm{~b}$ showed strong numerical and rank full correlations between female participation and some general economic variables, and Table 10 showed that, of the general economic variables, population density remained a strong correlate after controlling for the other variables. Taken together, the results suggest that population density was a key correlate of the participation of female labor in the industrial sector, supporting one of Locher-Scholten's key hypotheses.

\section{Conclusion}

The data from the Colonial Reports are a rich source of information for the study of female labor in industrial Indonesia. They provide a detailed picture of the position of women in the Netherlands Indies during its early industrialization, with significant implications for the analysis of the economics of gender in present-day Indonesia. This study has shown, first, that while women worked in a number of regions and sectors, their role was concentrated in specific sectors of the economy that accommodated "female" professions, such as the batik and kapok sectors. Second, women were substantially better integrated into the industrial sector in Java and Madura than they were in the Outer Islands, though their involvement in industry was low throughout the Netherlands Indies. Because Java and Madura were more "advanced" than the Outer Islands, which were still frontier economies, the opportunities for specialized light labor of the kind for which female labor was well-suited were greater in Java and Madura than they were in the Outer Islands. This availability of opportunity was shown in this study to be related to the density of population. Older and longer-settled economies, which had denser populations, also provided markets for the kinds of goods that are produced in non-subsistence economies, including those goods produced by trades that benefited from female-specific skills. Third, the nonsubsistence (industrial) sector employed smaller numbers of women relative to men than did the agricultural (subsistence) sectors, supporting a key assertion in the early literature on the role of women in development.

In the context of the "necessity vs. tradition" question discussed earlier in this paper, this study shows that, in the recently industrialized and sparsely populated high-wage industrial labor markets of the Outer Islands, women played a far smaller role in industry than they did in the better-established and more diverse industrial sector in densely-populated low-wage Java and Madura. This phenomenon is consistent with a variety of hypotheses. One is that, given the nature of the economies of the Outer Islands, perhaps there was little demand for the kinds of goods produced by specialized female labor. Or, while there was a need for female labor, because of the

62 For Java and Madura, mean population density across regions in 1920 was 274 people per square kilometer, and the standard deviation (a measure of variation across regions) of population density was 113. For the Outer Islands, the mean density was only eighteen people per square kilometer. Combining the two regions yielded a larger set of observations with a higher standard deviation of 153 . These figures were computed using the data in Peter Boomgaard and Abrahamine J. Gooszen, Changing Economy in Indonesia: Population Trends 1795-1942, Table 15, p. 218 (Java and Madura) and Table 22, p. 242 (Outer Islands). 
relative newness of the industrial sector in these regions, the institutions conducive to a market for female labor had yet to develop. Alternatively, perhaps the cultural differences between the two regions meant that female labor was never to play a role in the Outer Islands that paralleled its role in Java and Madura. Or, because of population density and the relative abundance of labor in Java and Madura, it was valued less. As a consequence, males in more families would have earned insufficient wages, forcing women out of the house and into the workplace to a greater degree than in the Outer Islands. Any combination of these four factors could be responsible for the observed pattern of female industrial labor across the Netherlands Indies in the late colonial period.

In order rigorously to test these hypotheses, more work needs to be done. Specific topics that need to be studied include the role of women in agriculture in the Outer Islands relative to their role in agriculture in Java and Madura. If women were as weakly represented in agriculture in the Outer Islands relative to Java as they were in industry, the cultural difference argument would seem important, as would the economic necessity argument (i.e., that in densely populated regions labor is less valued, a. situation that forces women out of the home). A second topic is that of growth of the role of women in industry in the Outer Islands, and whether it has begun to parallel their role in industry in Java and Madura. If this is the case, then the argument about institutions developing in order to yield efficient market outcomes would seem plausible, as would the twin hypotheses involving industrial diversity and economic necessity, if population densities in the Outer Islands have begun to approach those of Java. The resolution of these questions awaits detailed research on the position of women in agriculture in the Outer Islands in the early part of the twentieth century and parallel research on the role of women in agriculture and in industry today in Java and Madura and the Outer Islands. 
